\title{
LIQUEFACTION POTENTIAL ALONG WITH PORE WATER PRESSURE GENERATION OF COASTAL SAND OF DIGHA IN WEST BENGAL, INDIA
}

\author{
Pinak RAY* and Ramendu Bikas SAHU
}

Department of Civil Engineering, Jadavpur University, Kolkata - 700032, West Bengal, India

*Corresponding author's e-mail: pinak.ray@gmail.com

\begin{tabular}{l} 
ARTICLE INFO \\
\hline Article history: \\
Received 8 October 2020 \\
Accepted 16 March 2021 \\
Available online 6 April 2021 \\
\hline
\end{tabular}

Keywords:

Cyclic strength

Density of sand

Confining pressure

Initial liquefaction

Maximum shear modulus

Excess pore water pressure generation

\begin{abstract}
Stress controlled cyclic triaxial tests have been done on coastal sand of Digha, West Bengal, India, at different frequencies, confining pressures, and relative densities and cyclic stress ratios. Number of cycles for initial liquefaction $\left(\mathrm{N}_{\mathrm{L}}\right)$ has been determined for that number of cycle when excess pore pressure ratio has become equal to 1 . Significant influences of density of sand, confining pressure and number of cycles for initial liquefaction on coastal Digha sand have been found. The test results have shown that increasing density of sand increases liquefaction potential, whereas cyclic strength of sand decreases with increase of confining pressure. An empirical correlation has been developed on cyclic strength of sand based on these parameters and this correlation fits quite well with the observed experimental results. Bender Element tests have been performed to determine maximum shear modulus $\left(\mathrm{G}_{\max }\right)$ of Digha sand at different densities and confining pressures. A high correlation coefficient between cyclic strength and $\mathrm{G}_{\max }$ of Digha sand at any $\mathrm{N}_{\mathrm{L}}$ has been found. A new pore water pressure generation model has been introduced for this sand along with upper bound and lower bound curves to predict excess pore water pressure build up due to seismic loads.
\end{abstract}

\section{INTRODUCTION}

The high incidence of liquefaction during earthquakes and its damage potential has made analysis of cyclic strength of sand a prime subject of concern in the field of geotechnical earthquake engineering. Significant research on liquefaction of soils has been carried out earlier by several researchers, i.e. Seed and Lee (1966), Lee and Seed (1967), Peacock and Seed (1968), Lee and Fitton (1969), Seed and Peacock (1971), Finn et al. (1971), and Silver et al. (1976). But in India the study of dynamic soil properties and liquefaction potential of soil has been started in a little later stage only after devastation during Bhuj earthquake in Gujarat in the year 2001. One type of study has been carried out on soil from seismological active zones like Assam sand (Sitharam and Govindaraju, 2007) and on soils from earthquake affected damaged areas like Ahmedabad sand (Sitharam and Govindaraju, 2007) and Bhuj sand (Sitharam et al., 2004). Another type of study has been done on river sand like Kasai river sand (Chattaraj and Sengupta, 2016), Solani river sand (Maheshwari et al., 2012), Brahmaputra river sand (Kumar et al., 2017), Yamuna sand (Rao and Ramana, 2010) in order to evaluate their behaviour during earthquake. India is surrounded by sea in eastern region (Bay of Bengal), southern region (Indian Ocean) and western region
(Arabian Sea) and is very often experience ocean storms at least once in every year mainly during monsoon. Recently on May, 2020 devastating cyclone Amphan has made severe damage in the coastal areas in West Bengal comprising East Midnapur and South 24 Parganas. Further in the year 2000, eastern and southern coast experienced the effect of tsunami which caused a devastating damage in the coastal area.

Research works to determine liquefaction damage potential of coastal soil in eastern coastal region of India has not been carried out. Several research works on liquefaction of soils have been performed on coastal soil has been done in other countries like sand from the North Coast of Egypt (Salem et al., 2013), sand from beach in Puerto Real, Cabo Rojo, south-western Puerto Rico (Sandoval and Pando, 2012) and coastal sand from Dogs Bay (Hyodo et al., 1998).

In this present study coastal sand of Digha region has been selected for this study. Digha is situated between the coastal tract of adjacent Bay of Bengal and the boarder of two states: West Bengal and Orissa (Mandal et al., 2013). Moreover this area lies within the seismic zone III as per seismic zonation map of India (Dasgupta et al., 2000 and IS 1893). Digha is one of the most important tourist spots of West Bengal district where average annual inflow of number of 
tourists are around 1 million and the number reaches sometimes about 3 million (Mandal et al., 2013). For this tourism a huge number of hotels, restaurants, recreation centres and other construction have been done in Digha and also this number is increasing day by day. Apart from this, Digha consists of one of the biggest fishery industry in West Bengal (Mandal et al., 2013). So all types of important structures used for tourism; residential and industrial purposes have been constructed on the soil of Digha which is more or less uniform fine to medium sand (Dalal and Sahu, 2011; Jana and Bhattacharya, 2012). Another major problem in Digha region is the loss of land to sea which means high erosion of coast line at Digha, Shankarpur, Chandpur, Jaldha, Tajpur and Mandarmani (Jana and Bhattacharya, 2012) and rapid beach erosion at Old Digha associated with enormous damage of artificial construction at Bankipur along with beach accretion and development of new dunes at Talsari (Jana et al., 2013). The problem of coast line encroachment towards land and rapid beach erosion in Digha region has been identified along with evidential proof with photographs by Jana et al. (2013). The reason behind this phenomenon from geotechnical point of view is liquefaction i.e. development of excess pore water pressure due to tidal wave and storm surge, which causes rapid occurrence of beach erosion mainly in Old Digha region. Moreover in recent days, (dated $28^{\text {th }}$ August, 2018) an earthquake of moderate intensity of the magnitude level of five on the Richter scale occurred having epicentre at 10 kilometres below the surface of the district Hooghly, at Indian Standard Time 18:33:29 having location at $22.6^{\circ} \mathrm{N}$ and $87.7^{\circ} \mathrm{E}$ having source of Garhmayna Khandaghosh Fault (Indian Meteorological Department - Earthquake Report). Mild shaking was felt in East Midnapore, West Midnapore, Jhargram, Bankura, Purulia, Hooghly and Kolkata districts. Also, in recent past several number of shaking has occurred in those districts due to Pingla Fault, Garhmayna Khandaghosh Fault (Dasgupta et al., 2000). As Digha lies under seismic zone III (Dasgupta et al., 2000) and the soil profile is uniform sand (Dalal and Sahu, 2011) so there exists a high chance of damage due to liquefaction if earthquake of high magnitude strikes in this region.

In this regard a detail study regarding liquefaction potential and excess pore water pressure generation of coastal sand of Digha region has been found immense important. The study area of coastal soil has been selected between Taalsari to Shankarpur in Digha region having $21^{\circ} 37^{\prime} 59.196 "$ Northern Latitude and $87^{\circ} 32^{\prime} 37.2732^{\prime \prime}$ Eastern Longitude and it has been shown in map from Figure 1a and Figure $1 b$.

\section{BACKGROUND}

Failure of soil during liquefaction can be designated as when maximum excess pore water pressure $\left(\mathrm{u}_{\max }\right)$ becomes equal to effective over burden pressure or effective consolidation stress $\left(\sigma_{0}\right)$. So it can be stated that liquefaction of soil occurs for that particular number of cycle when pore water pressure ratio $\left(r_{u}\right)$ equals to $1\left(r_{u}=u_{\max } / \sigma_{o}=1\right)$ and that particular number of cycle can be designated as number of cycles required for initial liquefaction $\left(\mathrm{N}_{\mathrm{L}}\right)$. Various methods have been proposed by several

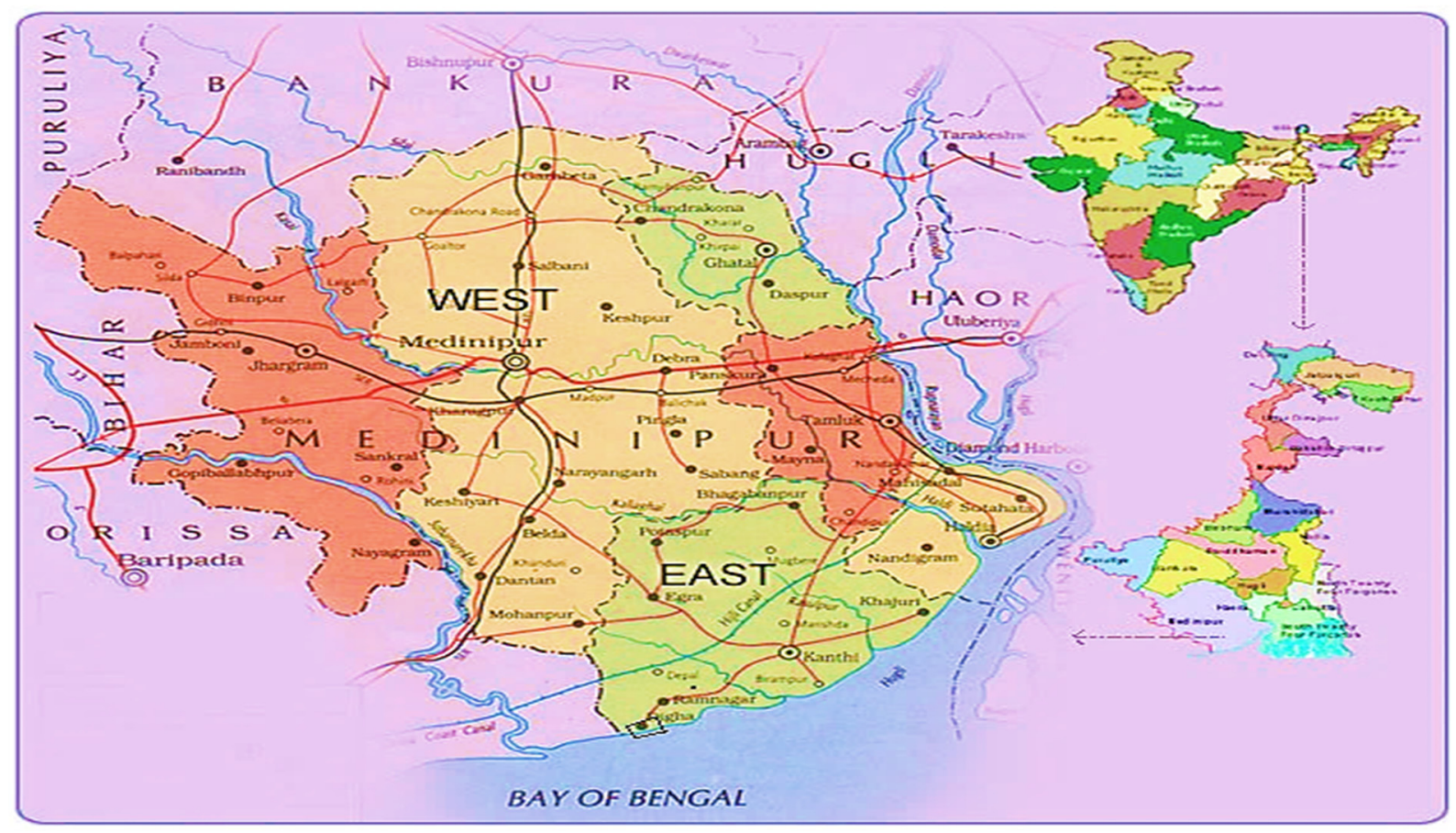

Fig. 1a Map of the study area under East Midnapore district of West Bengal in India (source: official website of Govt. of Midnapore - https://www.paschimmedinipur.gov.in). 


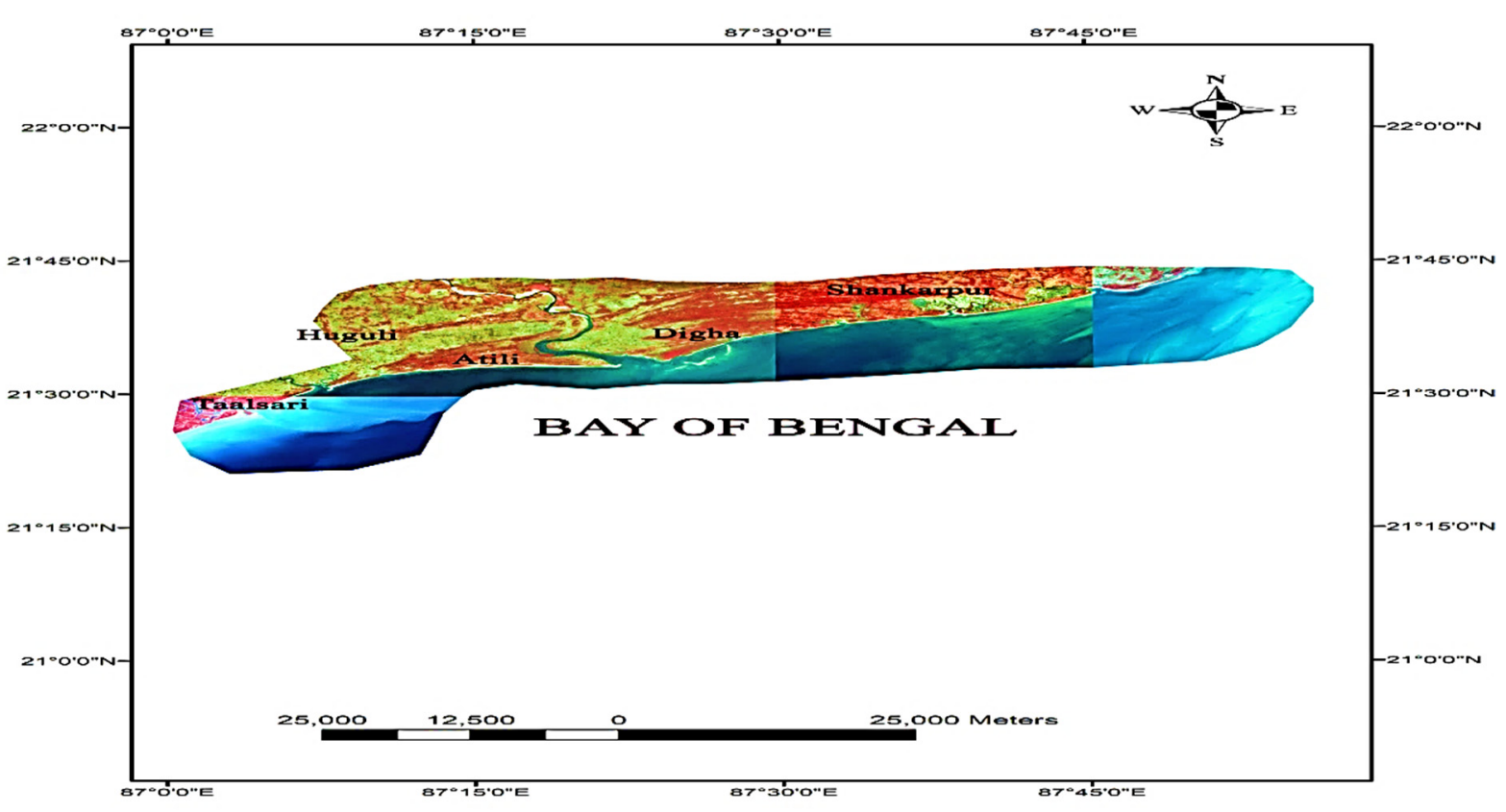

Fig. 1b Study area map showing Taalsari - Digha - Shankarpur location (source: Resourcesat-1: Liss-III satellite image of Bhvan, Indian Geo-platform of ISRO - website: https://bhuvan-app3.nrsc.gov.in).

researchers to evaluate liquefaction potential of soil, but by using stress controlled cyclic triaxial test the most suitable method is determination of number of cycles required for initial liquefaction for given Cyclic Stress Ratios (CSR) where CSR is defined as the ratio of cyclic shear stress, $\tau_{\text {cyc }}$ to effective over burden pressure, $\sigma_{\mathrm{o}}\left(\mathrm{CSR}=\tau_{\mathrm{cyc}} / \sigma_{\mathrm{o}}\right)$. But this failure criterion, $\mathrm{N}_{\mathrm{L}}$ is determined by for that cycle when $\mathrm{r}_{\mathrm{u}}$ reaches 1 or axial strain of the sample reaches $5 \%$ (5\% double amplitude strain, $\varepsilon_{\mathrm{d}}$ ), whichever is earlier. Several attempts have been made by researchers to find the effects of parameters which affect CSR of soil. Out of these parameters most important are: relative density i.e. soil characteristic (Seed and Lee, 1966; Lin et al., 2004; Finn et al., 1971; Hyodo et al., 1998; Rao and Ramana, 2010; Sandoval and Pando, 2012; Salem et al., 2013; Krim et al., 2016; Akhila et al., 2019); effective confining pressure i.e. geological criteria (Castro and Poulos, 1977; Yunoki et al., 1982; Salem et al., 2013; Finn et al., 1971; Peacock and Seed, 1968; Seed and Lee, 1966; Hyodo et al., 1998; Rao and Ramana, 2010) and frequency of loading of earthquake i.e. seismic criteria (Rao and Ramana, 2010; Townsend, 1977). The effect of number of cycles required for liquefaction $\left(\mathrm{N}_{\mathrm{L}}\right)$ on CSR has been investigated by earlier researchers (Seed and Lee, 1966; Silver et al., 1976; Lin et al., 2004; Evans and Zhou, 1995; Toki et al., 1986; Salem et al., 2013).

Correlation between cyclic strength of sand (CSR) with number of cycles required to reach initial liquefaction $\left(\mathrm{N}_{\mathrm{L}}\right)$ has been proposed earlier ( $\mathrm{Rad}$ and Clough, 1982; Chattaraj and Sengupta, 2016).
$C S R=a N_{L}^{-b}$

where, the coefficients $\mathrm{a}$ and $\mathrm{b}$ depend on relative density of sand.

The cyclic strength of soil (CSR) also depends on maximum shear modulus (De alba et al., 1984; Chattaraj and Sengupta, 2016). First effort to correlate between CSR and $\mathrm{G}_{\max }$ has been introduced by De alba et al., 1984; but the drawback of this correlation was valid only for $\mathrm{N}_{\mathrm{L}}=10$. This drawback has been overcome by the new correlation proposed by Chattaraj and Sengupta, 2016; where it has been found that the correlation between CSR and $G_{\max }$ is valid for any number of failure cycle $\left(\mathrm{N}_{\mathrm{L}}\right)$ but this correlation is limited to effective confining pressure remains $100 \mathrm{kPa}$.

During dynamic loading in a saturated soil sample the pore water pressure generation is the most important and significant parameter. Not only that particular number of cycle in which the excess pore water pressure ratio becomes equal to 1 is important, but also the nature or trend of pore water pressure generation during cyclic loading; its dependency on several parameters along with upper bound and lower bound limit of excess pore water pressure generation should be taken into account for study and analysis of liquefaction of sand. Significant research to study the pore water pressure generation has been done by strain controlled cyclic triaxial test (Vucetic and Dobry, 1988; Dobry et al., 1982; Sitharam, and Govindaraju, 2007; Sitharam et al., 2008); by stress controlled cyclic triaxial test (Chattaraj and Sengupta, 2016; Rao and Ramana, 2010); by cyclic simple shear test (Porcino and Diano, 2016); by stress-controlled cyclic 
hollow torsional tests (Baziar et al., 2011; Konstadinoun and Georgiannou, 2014). Several numerical model of excess pore water pressure generation model have been proposed by the previous researchers. Moreover during excess pore water pressure generation in sand upper bound and lower bound curve of pore water pressure generation has been proposed (Talaganov, 1996; Dobry, 1985; Baziar et al., 2011; Lee and Albaisa, 1974; EL Hosri et al., 1984; Seed et al., 1976). Pore water pressure generation during stress controlled cyclic triaxial test depends on number of loading cycles, relative density and amplitude of applied cyclic stress (Govindaraju, 2005).

In this regard stress controlled cyclic triaxial tests have been carried on coastal Digha sand to determine its cyclic strength (CSR) by considering the parameters of frequency of loading, density of sand, effective confining pressure and number of cycles of loading which causes liquefaction. A new correlation of CSR of this sand has been established by considering these parameters.

From bender element test maximum shear modulus of Digha sand has been determined and its correlation with CSR value of sand at different confining pressure has been established and it has been compared with the experimental results of Kasai sand (Chattaraj and Sengupta, 2016). A new excess pore water pressure generation model has been built up from experimental results of stress controlled cyclic triaxial tests and upper bound and lower bound model has been proposed. Experimental test results of pore water pressure generation of clean sand (Sitharam, et al., 2008) and Yamuna sand (Rao and Ramana, 2010) have been used to validate the significance these two boundary curves of pore water pressure generation.

\section{MATERIAL CHARACTERISTICS}

The coastal Digha sand in this present study has been collected from Taalsari - Digha - Shankarpur region shown in Figure 1b. The index properties of
Digha sand has been determined as per IS: 2720 (Part-3), and IS: 2720 (Part-14) and shown in Table 1 and the grain size distribution curve is shown in Figure 2. The soil has been classified as poorly graded sand (SP) as per ASTM D 2487. It has been seen in Figure 2 that the grain size distribution curve lies between liquefiable boundaries proposed by Tsuchida, 1970 and reproduced by Xenaki and Athanasopoulos (2003). So it may be concluded from Figure 2 that the sand sample which has been selected has high liquefaction susceptibility.

\section{SAMPLE PREPARATION}

For both cyclic triaxial test and Bender Element test all the soil samples have been prepared by a cylindrical split mould of size $50 \mathrm{~mm}$ diameter and $100 \mathrm{~mm}$ height. As per ASTM 5311 - 11 the oven dried sand samples have been prepared by tamping method in 5 layers. If the target relative density is $R_{d} \%$, then relative densities are from bottom to top are $R_{d}-2, R_{d}-1, R_{d}, R_{d}+1, R_{d}+2$ respectively. By selecting the relative density for each layer the weight of sand along with height of each layer to be maintained has been calculated. A cone shaped funnel with a long tube has been used to pour the specimen into the split mould for each layer by maintaining zero dropping height. After filling each layer into the mould, tamping is applied till it occupies the particular height for each layer. Suction pressure of $10-12 \mathrm{kPa}$ was applied to the sample to make the sample stiff, vertical and to reduce disturbance before removing the mould. Four target relative densities of $25 \%, 45 \%$, $65 \%$ and $85 \%$ have been selected in this present study along with four different effective confining pressures of $50 \mathrm{kPa}, 100 \mathrm{kPa}, 200 \mathrm{kPa}$ and $400 \mathrm{kPa}$. Saturation has been done with de aired distilled water by applying back pressure and it has been increased gradually by maintaining effective confining pressure (difference between cell pressure and back pressure) $10 \mathrm{kPa}$ until Skempton's pore pressure coefficient value, $\mathrm{B}\left(\mathrm{B}=\Delta \mathrm{u} / \Delta \sigma_{\mathrm{c}}\right.$, where $\Delta \mathrm{u}$ is change in pore water

Table 1 Physical properties of Digha sand.

\begin{tabular}{lll}
\hline Property & Notations & Value \\
\hline Specific Gravity & $\mathrm{G}_{\mathrm{s}}$ & 2.72 \\
\hline Grain Size (mm) & $\mathrm{D}_{60}$ & 0.3 \\
& $\mathrm{D}_{50}$ & 0.26 \\
& $\mathrm{D}_{30}$ & 0.19 \\
& $\mathrm{D}_{10}$ & 0.123 \\
\hline Uniformity coefficient & $\mathrm{C}_{\mathrm{u}}$ & 2.44 \\
\hline Coefficient of curvature & $\mathrm{C}_{\mathrm{c}}$ & 0.978 \\
\hline Maximum dry density $(\mathrm{g} / \mathrm{cc})$ & $\gamma_{\mathrm{dmax}}$ & 1.61 \\
\hline Minimum dry density $(\mathrm{g} / \mathrm{cc})$ & $\gamma_{\mathrm{dmin}}$ & 1.37 \\
\hline Maximum void ratio & $\mathrm{e}_{\max }$ & 0.978 \\
\hline Minimum void ratio & $\mathrm{e}_{\min }$ & 0.692 \\
\hline Soil type as per the Indian Standard Soil & $\mathrm{SP}$ & Poorly graded sand \\
Classification System (ISSCS) & & \\
\hline
\end{tabular}




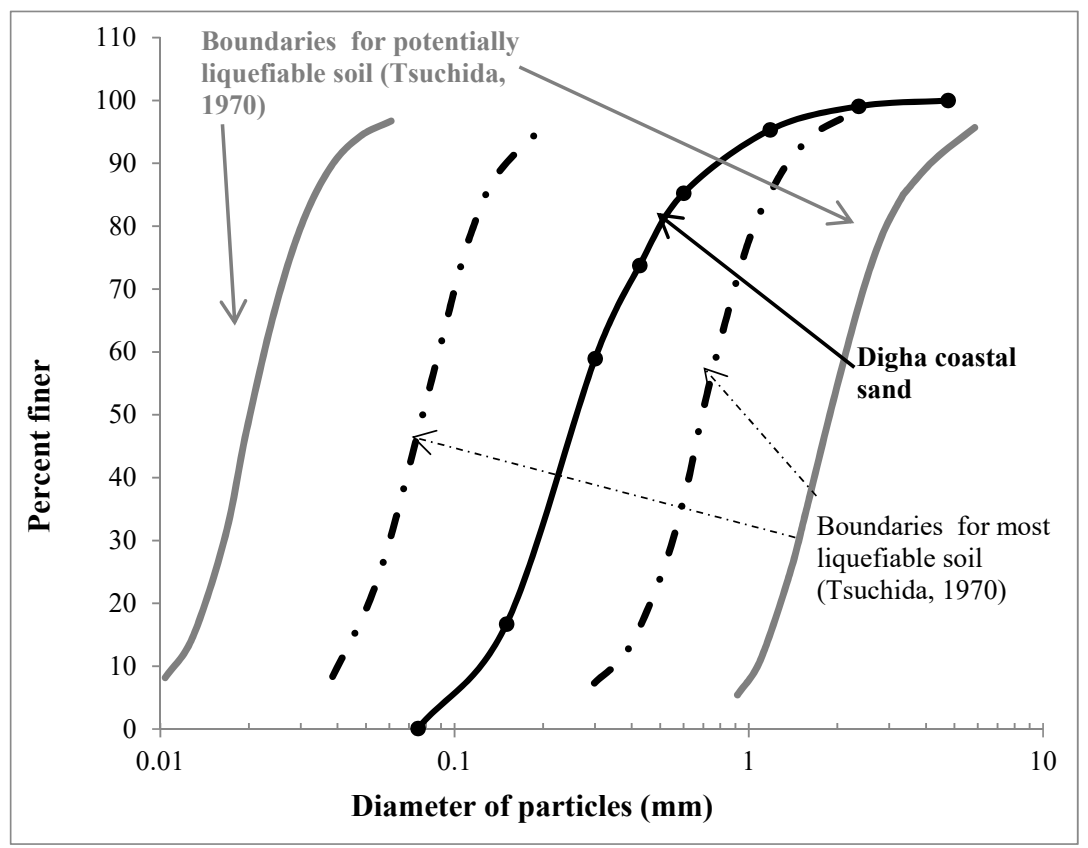

Fig. 2 Grain size distribution curve of Digha sand with liquefiable boundary (Tsuchida, 1970).

pressure and $\Delta \sigma_{\mathrm{c}}$ is change in cell pressure) exceed 0.95. Then the sand sample has been consolidated isotropic by maintaining the effective confining pressure $\left(\sigma_{0}\right)$ value of that amount in which the test program has been decided to conduct i.e. $\sigma_{\mathrm{o}}=50,100$, 200 and $400 \mathrm{kPa}$.

\section{TESTING PROGRAMME}

\subsection{CYCLIC TRIAXIAL TEST}

The cyclic triaxial test has been conducted as per ASTM: 5311-11 after completion of the consolidation process to determine cyclic strength (liquefaction potential) of soil by stress controlled technique. The saturated and consolidated sand specimen has been subjected to cyclic load by a loading rod which is connected to the top platen of the specimen under undrained condition by closing the back pressure valve in the loading frame. During application of cyclic load, the pore water pressure in the specimen increases. As a result, the effective stress in the specimen decreases and axial deformation of the specimen increases. The failure has been determined as that number of load cycles when excess pore water pressure ratio $\left(r_{u}\right)$ becomes equal to 1 , which is called initial liquefaction and that number of cycle to cause initial liquefaction is denoted as, $\mathrm{N}_{\mathrm{L}}$. These pore water pressure generations, cyclic loading on the soil specimen as well as axial deformation of the specimens have been displayed as well as recorded by the software provided by M/s HEICO named as Cyclic System Console V1.0.0 in a computer. The hydraulic actuator connected to a load cell (capacity $10 \mathrm{kN}$ ) which has been used in this test program can perform sinusoidal loading which can operate at a frequency of
0.01 to $10 \mathrm{~Hz}$. The specimen can be tested at a confining pressure upto $1000 \mathrm{kPa}$ and the cell pressure and back pressure both can be applied by digitally controlled pressure system along with a control panel which has a combination of electro pneumatic regulators.

The test conditions for cyclic loadings by performing stress controlled tests have been achieved as follows:

The cyclic stress ratio value of $0.15,0.20 .25$ and 0.3 has been selected for soil sand sample having relative density of $25 \%$ and $45 \%$. For relative density $65 \%$ and $85 \%$ CSR value has been chosen as 0.2 , $0.25,0.3$ and 0.35 . For each test confining pressure has been varied as 50,100, 200 and $400 \mathrm{kPa}$. So total 64 stress controlled cyclic triaxial test has been done in this study at sinusoidal harmonic loading having an applied frequency of $1 \mathrm{~Hz}$.

To study effect of frequency on liquefaction potential two set of cyclic triaxial tests have been performed, where during the first set the soil sample having relative density $25 \%$ and effective confining pressure of $50 \mathrm{kPa}$ has been chosen where the frequency range has been varied as $0.5,1$ and $2 \mathrm{~Hz}$ by taking the CSR values from 0.15 to 0.3 and during second set the soil sample having relative density $85 \%$ and effective confining pressure of $100 \mathrm{kPa}$ has been chosen where the frequency range has been varied as $0.5,1$ and $2 \mathrm{~Hz}$ by taking the CSR values from 0.2 to 0.35 .

\subsection{BENDER ELEMENT TEST}

Shear modulus of soil at small strain (less than $10^{5}$ ) is considered as maximum shear modulus, $G_{\max }$ 
(Chattaraj and Sengupta, 2016). To measure maximum shear modulus of soil Bender Element test has been performed. The test apparatus used in this study has been manufactured by $\mathrm{M} / \mathrm{s}$ HEICO. Cylindrical sample of coastal Digha sand has been prepared by a split mould of $50 \mathrm{~mm}$ diameter and $100 \mathrm{~mm}$ height for this study (described in section 4). In a triaxial apparatus the bender elements are installed. Bender elements are encapsulated and mounted in inserts that are fixed into the base pedestal platen and top cap platen of a triaxial cell. They are carefully inserted into the soil specimen. When excited the bender element bends from side to side pushing the soil in a direction perpendicular to the length of the element thus having a large coupling factor with the soil.

This produces a shear wave, which propagates parallel to the length of the element into the soil sample. On the other end of the soil sample another bender element is forced to bend and produces an electrical signal.

A shear wave is transmitted from the transmitter which is mounted in the top cap, where the shear wave is generated by an excitation voltage and the generated shear wave which propagates through the soil, is received by a receiver which is mounted in the pedestal. The apparatus of Bender element supplied by $\mathrm{M} / \mathrm{s}$ HEICO has the following technical specification:

- Maximum working pressure: $3500 \mathrm{kPa}$

- Multi-frequency test: up to $100 \mathrm{kHz}$

- Multi wave generator (sine, haversine, morlet)

- Suitable for specimen with diameters ranging from 50 to $150 \mathrm{~mm}$

After completion of saturation process in the sand sample prepared at a particular relative density, the effective confining pressure of 50, 100, 200 and $400 \mathrm{kPa}$ has been applied by changing the difference between cell pressure and back pressure value. Then the shear wave is transmitted and the travel time $(\mathrm{t})$ to reach the shear wave to the receiver is calculated. From this, the shear wave velocity $\left(\mathrm{v}_{\mathrm{s}}\right)$ in $\mathrm{m} / \mathrm{s}$ is calculated as:

$v_{s}($ in $m / s)=\frac{l}{t}$

where, $1=$ travel length of shear wave $(\mathrm{m})$

$\mathrm{t}=$ travel time of shear wave $(\mathrm{s})$

$\mathrm{G}_{\max }$ in $\mathrm{kPa}$ is calculated as:

$G_{\max }=\gamma \cdot v_{s}^{2}$

where, $\gamma=$ density of the soil specimen $\left(\mathrm{kg} / \mathrm{m}^{3}\right)$

So total 16 numbers of bender element tests have been performed, taking four relative densities of the soil sample i.e. $25 \%, 45 \%, 65 \%$ and $85 \%$ and for each relative density of the soil sample four confining pressure has been taken, i.e. $50,100,200$ and $400 \mathrm{kPa}$. So total sixteen $\mathrm{G}_{\max }$ value of the coastal Digha sand has been obtained for each condition of density and confining pressure.

\section{RESULTS AND DISCUSSION 6.1. CYCLIC TRIAXIAL TEST RESULTS}

Typical test results of stress controlled cyclic triaxial test for coastal Digha sand has been shown in Figure $3 \mathrm{a}$ to Figure $3 \mathrm{c}$. All the cyclic triaxial tests have been performed as two way cyclic loading which means reversal of cyclic shear stresses (compression and extension at a single cycle of loading). For the stress-controlled cyclic triaxial test, the magnitude of applied deviator stress, $\sigma_{\mathrm{d}}(\mathrm{kPa})$ has been estimated from the cyclic stress ratio (CSR) value and the particular effective confining pressure during the cyclic test by using Equation 4.

$\sigma_{d}=2 \times \sigma_{o} \times C S R$

Figure $3 \mathrm{a}$ shows the applied deviator stress vs. no. of cycles for coastal Digha sand at $R_{d}=45 \%$, $\sigma_{\mathrm{o}}=100 \mathrm{kPa}$ and applied CSR $=0.3$. So by using Equation 4 it can be calculated the applied deviator stress is $60 \mathrm{kPa}$. As all the tests are stress controlled test so the applied deviator stress is constant throughout each entire test program. The response of soil sample during liquefaction has been found out in Figure $3 b$ from the graph of axial strain, $\varepsilon_{a}(\%)$ vs. no. of loading cycles. It has been observed when the sample has started losing its strength (after $20^{\text {th }}$ number of cycles the deformation of the sample starts increasing. When the sample fails due to rise of excess pore water pressure equal to effective confining pressure (at $38^{\text {th }}$ number of cycles) the deformation of the sample becomes very large. The reason behind this phenomenon is that during liquefaction the sample loses its strength completely, so during application of cyclic loading by the actuator, the sample (which has lost its strength completely) deforms very high for applying the same amount of deviator stress $(\mathrm{q}=60 \mathrm{kPa})$ with respect to no liquefied soil sample. The excess pore water pressure generation during cyclic loading has been illustrated in Figure $3 \mathrm{c}$ for applied CSR $=0.3$ and effective confining pressure $=100 \mathrm{kPa}$ at four relative densities, i.e. $25 \%$, $45 \%, 65 \%$ and $85 \%$. It has been observed that at lower value of relative density the soil loses its strength quickly rather than in dense state. So the generation of excess pore water pressure during cyclic loading is much faster for sand in loose state with respect to sand in dense state. Figure $3 \mathrm{c}$ depicts the generation of excess pore water pressure generation at a constant effective confining pressure of $100 \mathrm{kPa}$. So it has been found that when the maximum excess pore water pressure, $\mathrm{u}_{\max }$ has become equal to $100 \mathrm{kPa}$ (effective confining pressure), the liquefaction occurs in that soil sample. It has been clearly observed in Figure $3 \mathrm{c}$ that for relative density $45 \%$ and applied $\mathrm{CSR}=0.3$ the soil liquefies at $38^{\text {th }}$ number of loading cycles because at $38^{\text {th }}$ numbered cycle $u_{\max }$ has become equal to $100 \mathrm{kPa}$ (effective confining pressure). The four curves of excess pore water pressure generation have been shown to compare and understand the excess pore pressure generation with variation of relative density. 


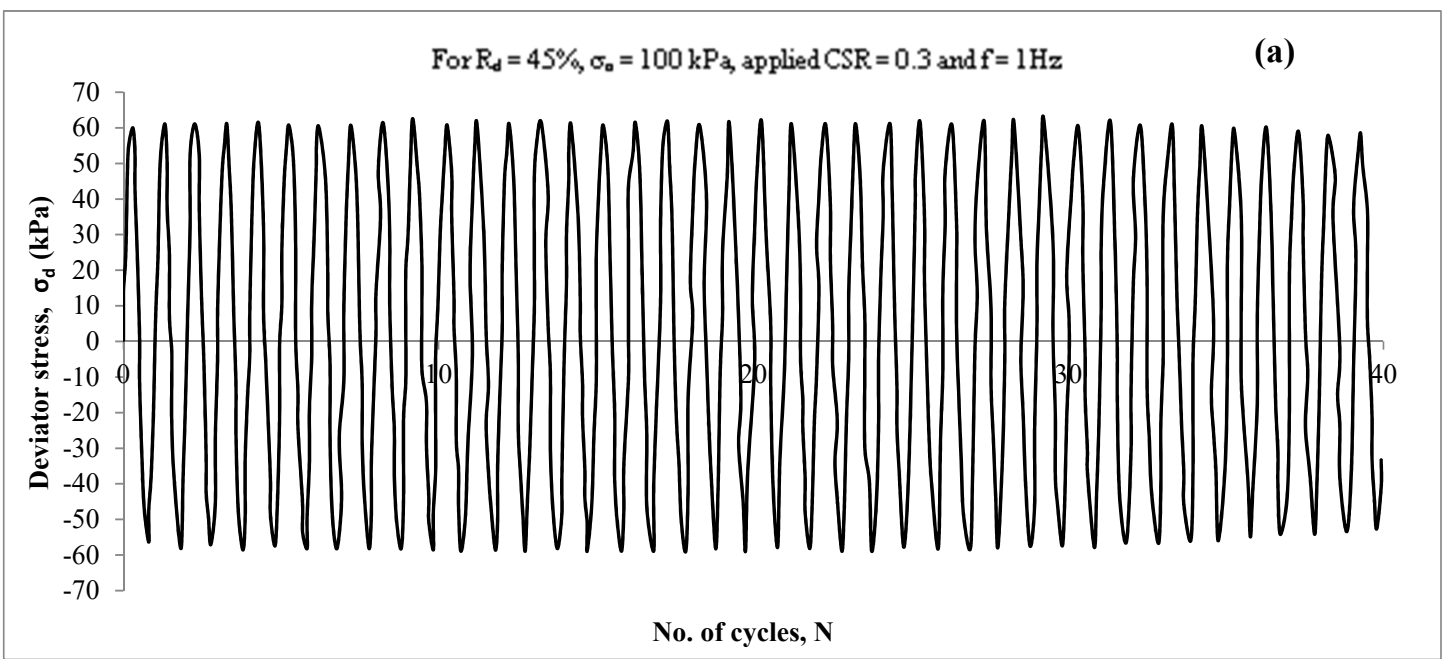

Fig. 3a Typical test result of applied deviator stress vs. number of cycles during cyclic loading for Digha sand.

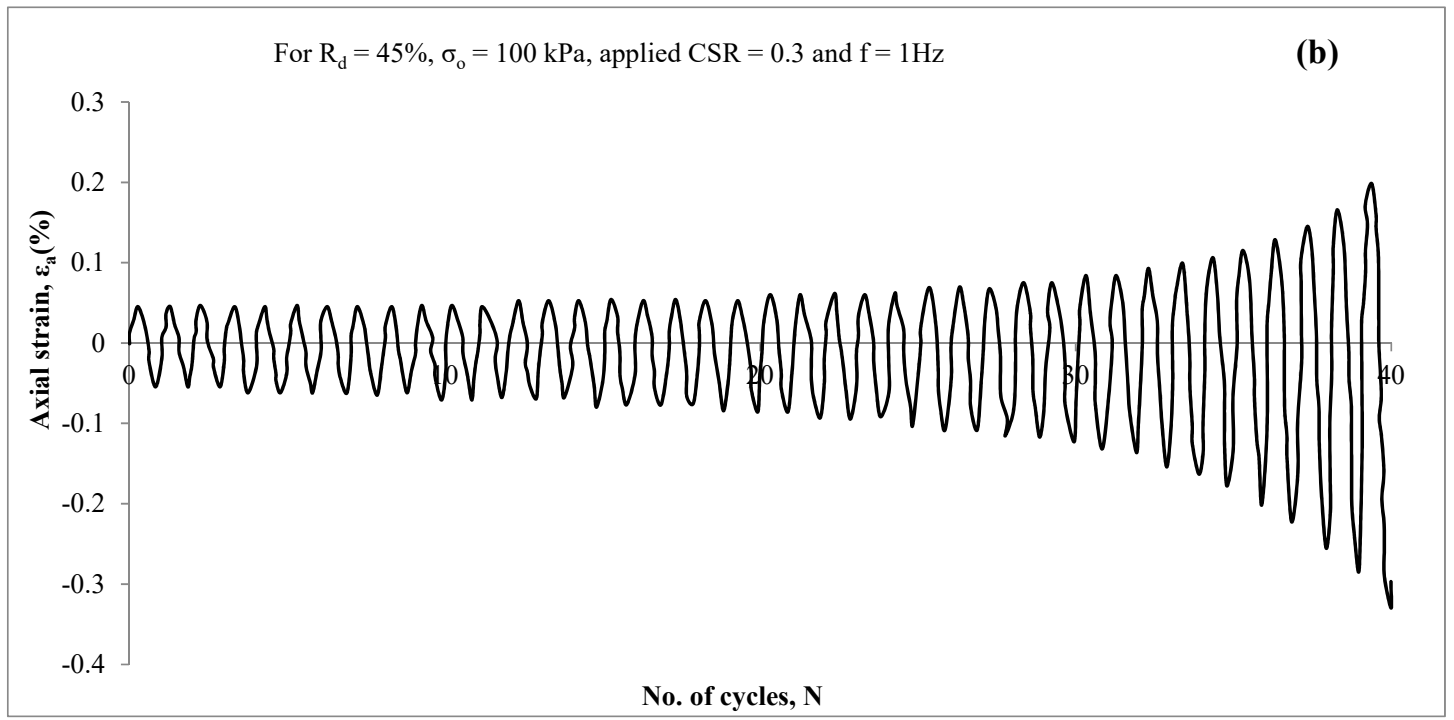

Fig 3b Typical test result of response of axial strain vs. number of cycles during cyclic loading for Digha sand.

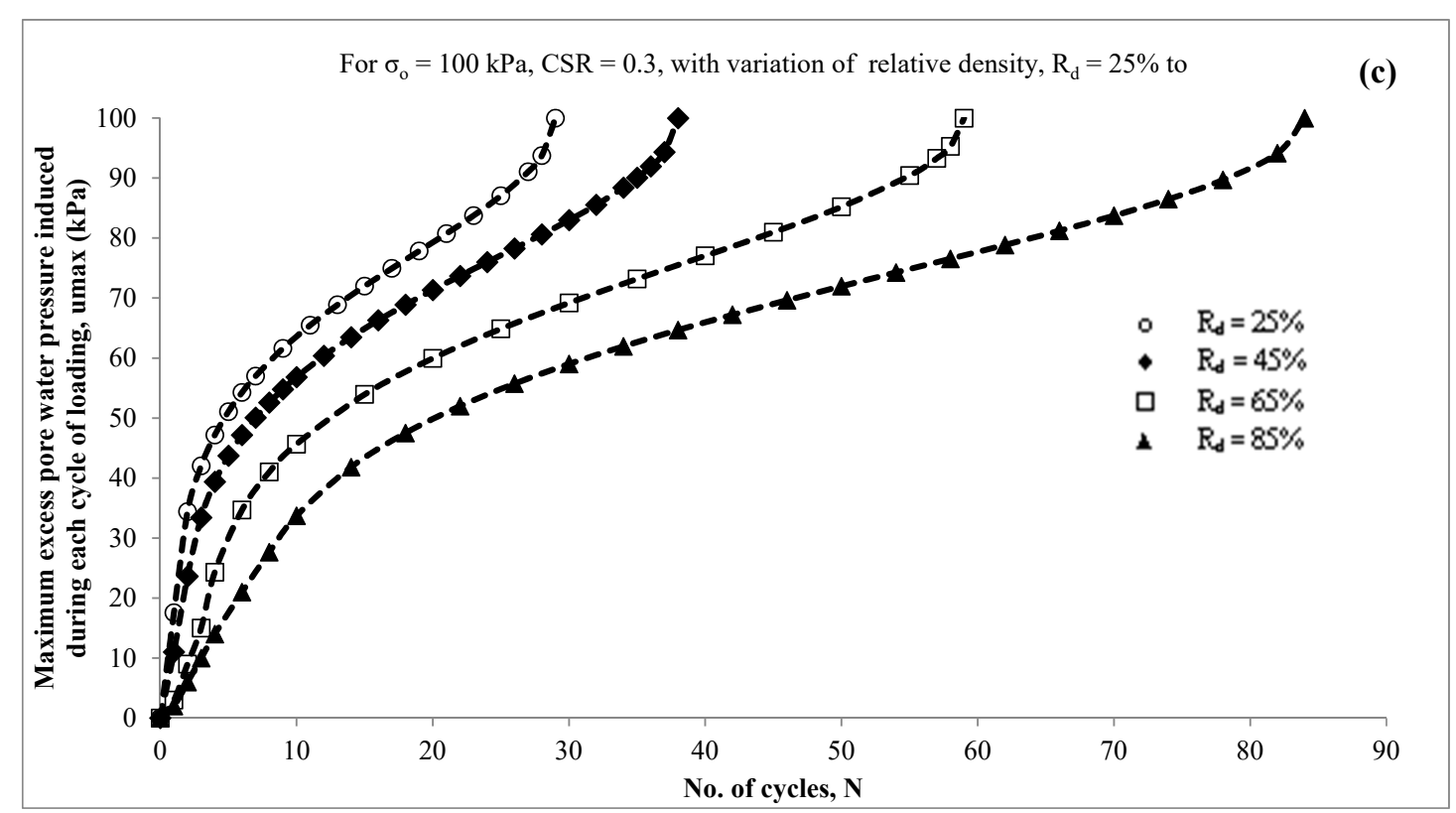

Fig. 3c Typical test result of generation maximum excess pore water pressure induced during each cycle of loading vs. number of loading cycles during cyclic triaxial test for Digha sand. 


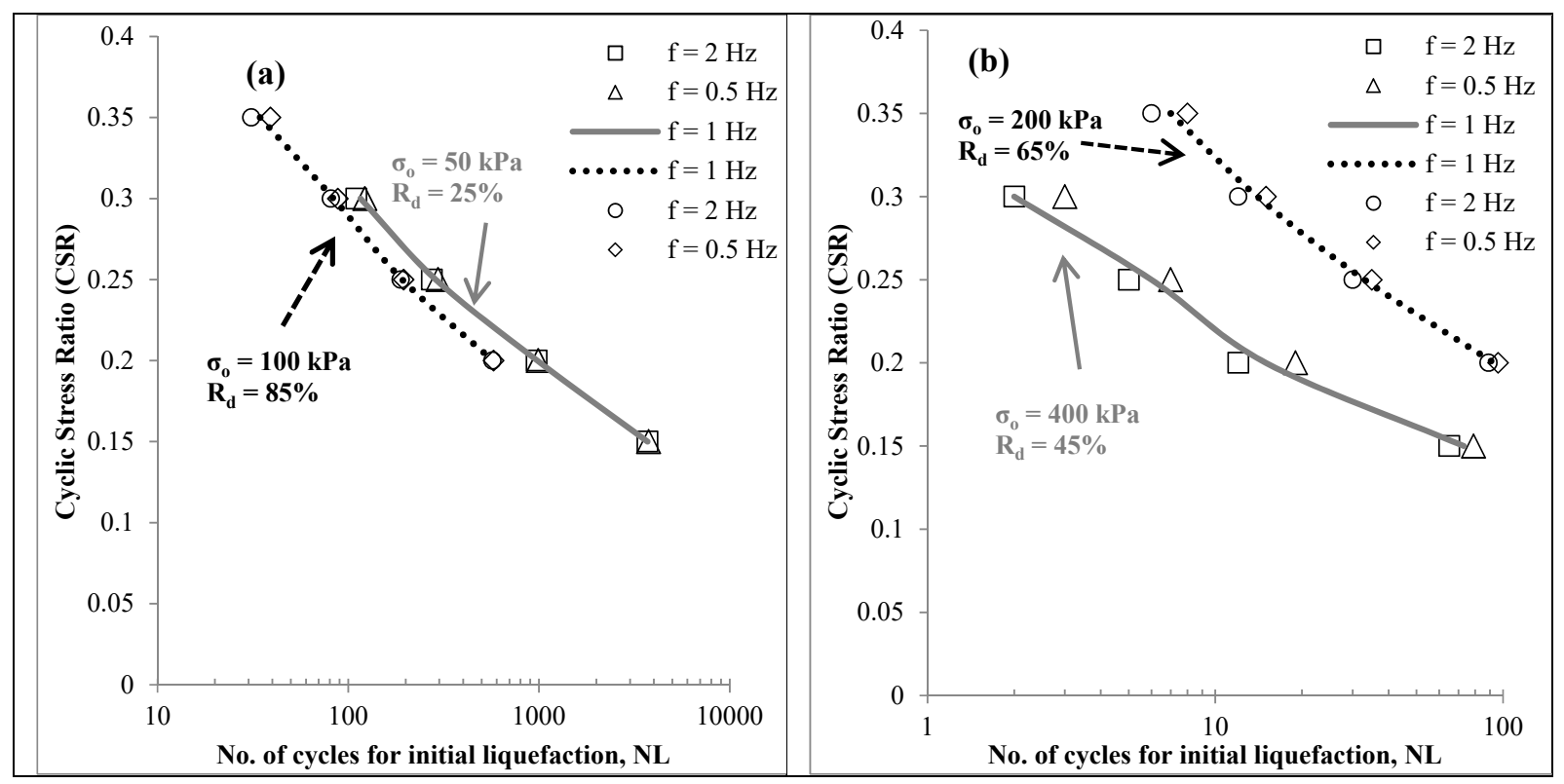

Fig. 4 Effect of frequency on CSR values of sand for (a) $R_{d}=25 \%$ and $85 \%$ and (b) $R_{d}=45 \%$ and $65 \%$.

\subsection{EFFECT OF FREQUENCY ON CYCLIC STRENGTH OF SOIL}

To investigate the effect of frequency on cyclic strength of soil cyclic triaxial tests have been done on coastal Digha sand at 3 frequencies i.e. $0.5,1$ and $2 \mathrm{~Hz}$. Soil sample has been prepared at $\mathrm{R}_{\mathrm{d}}=25 \%$ at $\sigma_{\mathrm{o}}=50 \mathrm{kPa}$ and at $\mathrm{R}_{\mathrm{d}}=85 \%$ at $\sigma_{\mathrm{o}}=100 \mathrm{kPa}$. For each frequency CSR value has been varied from 0.15 to 0.3 (for $\mathrm{R}_{\mathrm{d}}=25 \%$ ) and 0.2 to 0.35 (for $\mathrm{R}_{\mathrm{d}}=85 \%$ ). Figure 4 illustrates the effect of frequency on cyclic strength of soil. It has been found that frequency of load application does not influence the liquefaction resistance. Similar finding has been found by Townsend (1977), Rao and Ramana (2010). In this regard, all other cyclic triaxial tests have been done at sinusoidal loading frequency of $1 \mathrm{~Hz}$.

\subsection{DEPENDENCY OF CYCLIC STRENGTH OF SOIL ON NUMBER OF CYCLES}

Figure 5 illustrates the results of 64 numbers of cyclic triaxial tests. Soil sample has been prepared at relative density $25 \%, 45 \%, 65 \%$ and $85 \%$. For each density effective confining pressure of 50, 100, 200 and $400 \mathrm{kPa}$ has been applied. CSR value of 0.15 to 0.3 has been taken for relative density $25 \%$ and $45 \%$ and CSR value of 0.2 to 0.35 has been taken for relative density $65 \%$ and $85 \%$. It has been found that CSR value of soil reduces non-linearly with increase of number of cycles to cause initial liquefaction, $\mathrm{N}_{\mathrm{L}}$. So it can be stated that increase in loading amplitude (CSR value) increase rapid acceleration of excess pore water pressure in soil, as a result lesser number of loading cycles are required to liquefy of sand. Similar trend has been found by previous researchers (Seed and Lee, 1966; Silver et al., 1976; Lin et al., 2004; Evans and Zhou, 1995; Toki et al., 1986; Salem et al., 2013).

\subsection{EFFECT OF DENSITY AND CONFINING PRESSURE ON NUMBER OF CYCLES TO LIQUEFY}

To analyze cyclic strength of sand on number of cycles to liquefy (Fig. 5) and to determine the effects of parameter on liquefaction resistance of sand, a detail study has been done by concentrating only on the effect of density and confining pressure on number of cycles required for initial liquefaction $\left(\mathrm{N}_{\mathrm{L}}\right)$. Figure 6 shows the effect of effective confining pressure $\left(\sigma_{\mathrm{o}}\right)$ on number of cycles to liquefy for different cyclic stress ratios values i.e. 0.15 to 0.3 for $R_{d}=25 \%$ and for CSR values i.e. 0.2 to 0.35 for $\mathrm{R}_{\mathrm{d}}=85$. It has been observed that number of cycles to liquefy for initial liquefaction decreases with increase in effective confining pressure. Similar trend or similar nature has been observed by other researchers also (Salem et al., 2013; Finn et al., 1971; Castro and Poulos, 1977; Sandoval and Pando, 2012). But this observation is contradicting in nature with observed result of other researchers (Seed and Lee, 1966; Peacock and Seed, 1968; Rao and Ramana, 2010) where number of cycles to liquefy increases with increase of effective confining pressure. This observation can be explained as the sand has become saturated and consolidated before cyclic loading, so increase in effective confining pressure (before application of shearing by cyclic loading) squeezes the voids space between sand particles and increases the pore water pressure inside the sand. So when cyclic loading has been applied to the sand sample less number of loading cycles are required to reach excess pore water pressure equal to effective confining pressure (initial liquefaction).

Figure 7 illustrates the effect of density on number of cycles required to liquefy. It has been observed that with increase of density, strength of the soil sample increases. As a result more number of 


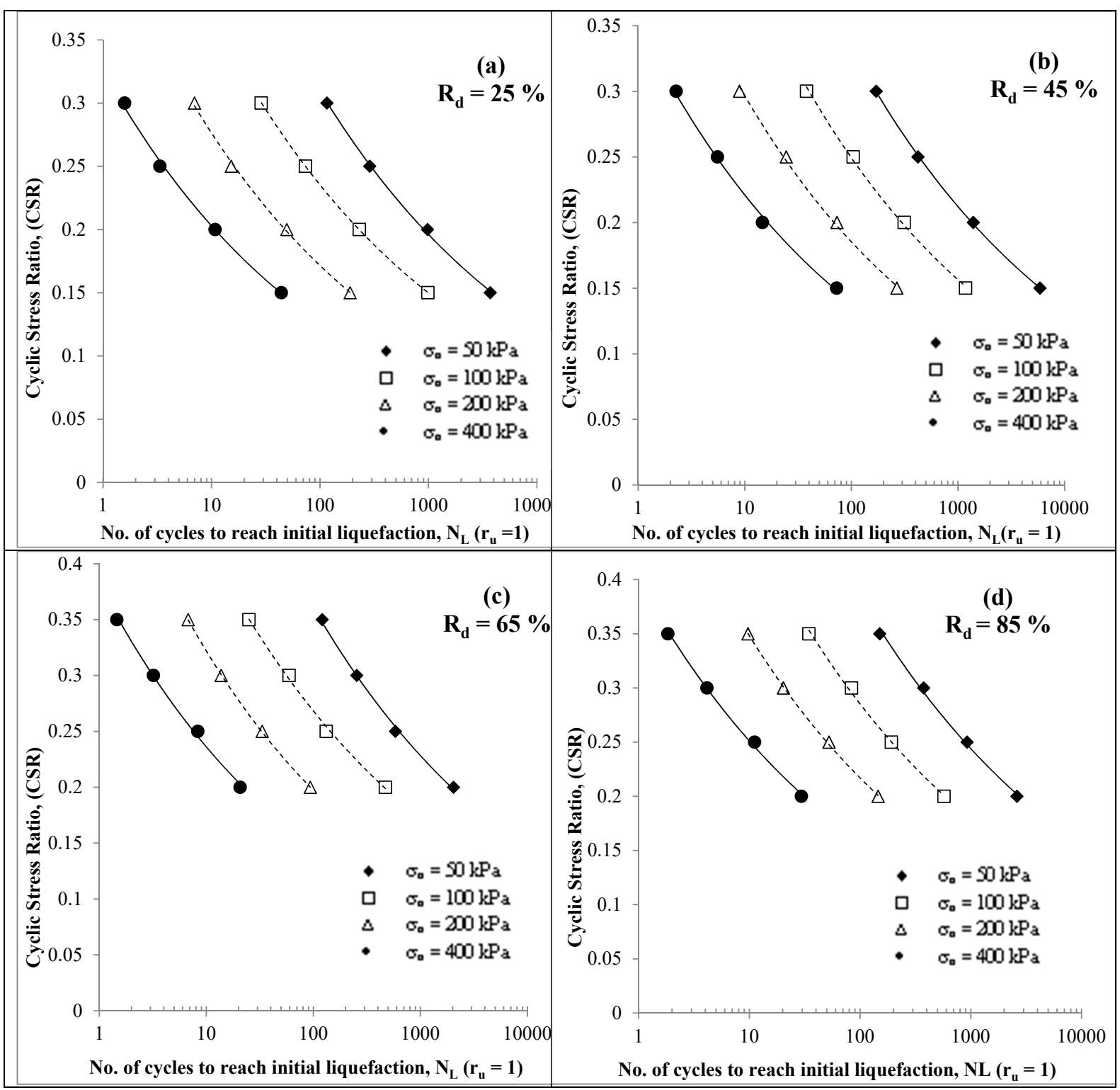

Fig. 5 Variation of cyclic stress ratio with number of cycles to reach initial liquefaction by varying confining pressures from $50 \mathrm{kPa}$ to $400 \mathrm{kPa}$ at (a) $\mathrm{R}_{d}=25 \%$; (b) $\mathrm{R}_{\mathrm{d}}=45 \%$; (c) $\mathrm{R}_{\mathrm{d}}=65 \%$; (d) $\mathrm{R}_{\mathrm{d}}=85 \%$.

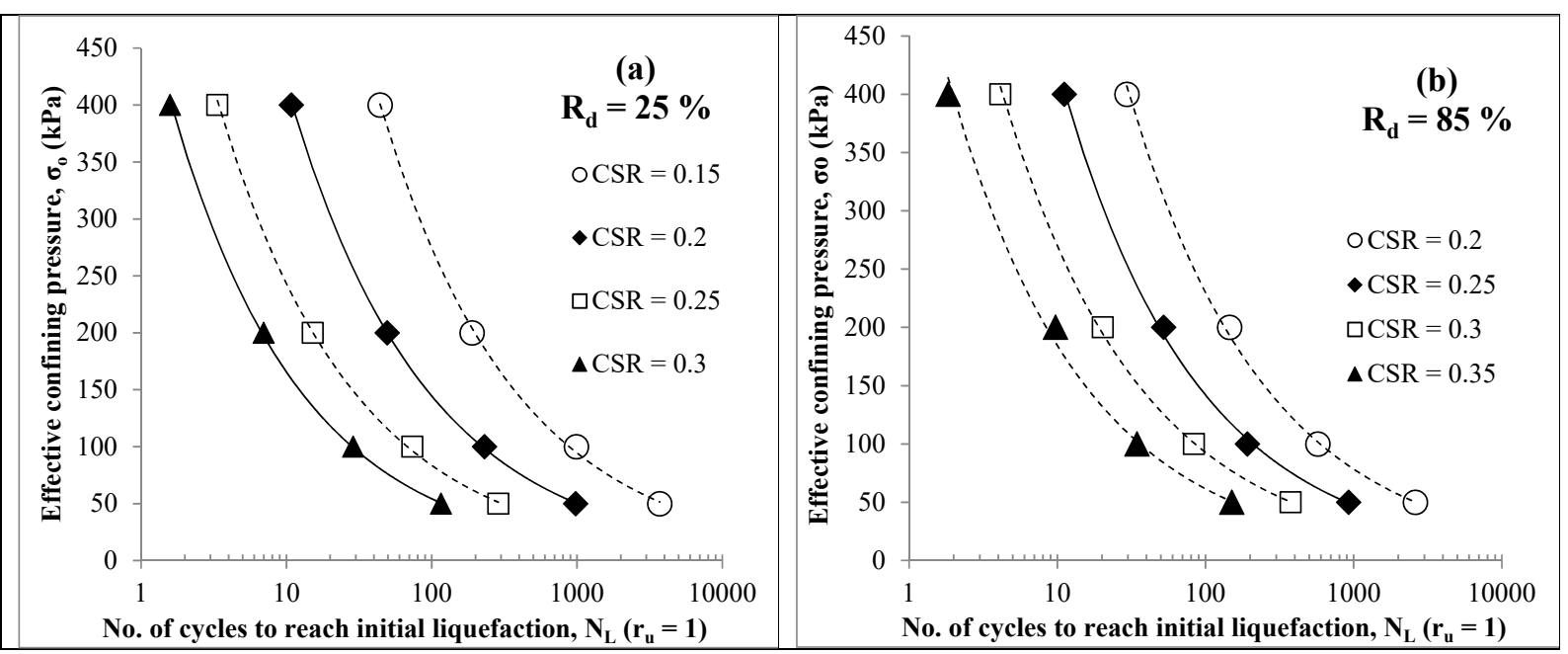

Fig. 6 Effect of confining pressure on number of cycles to liquefy for different cyclic stress ratios at (a) $R_{d}=25 \%$ and at (b) $R_{d}=85 \%$. 


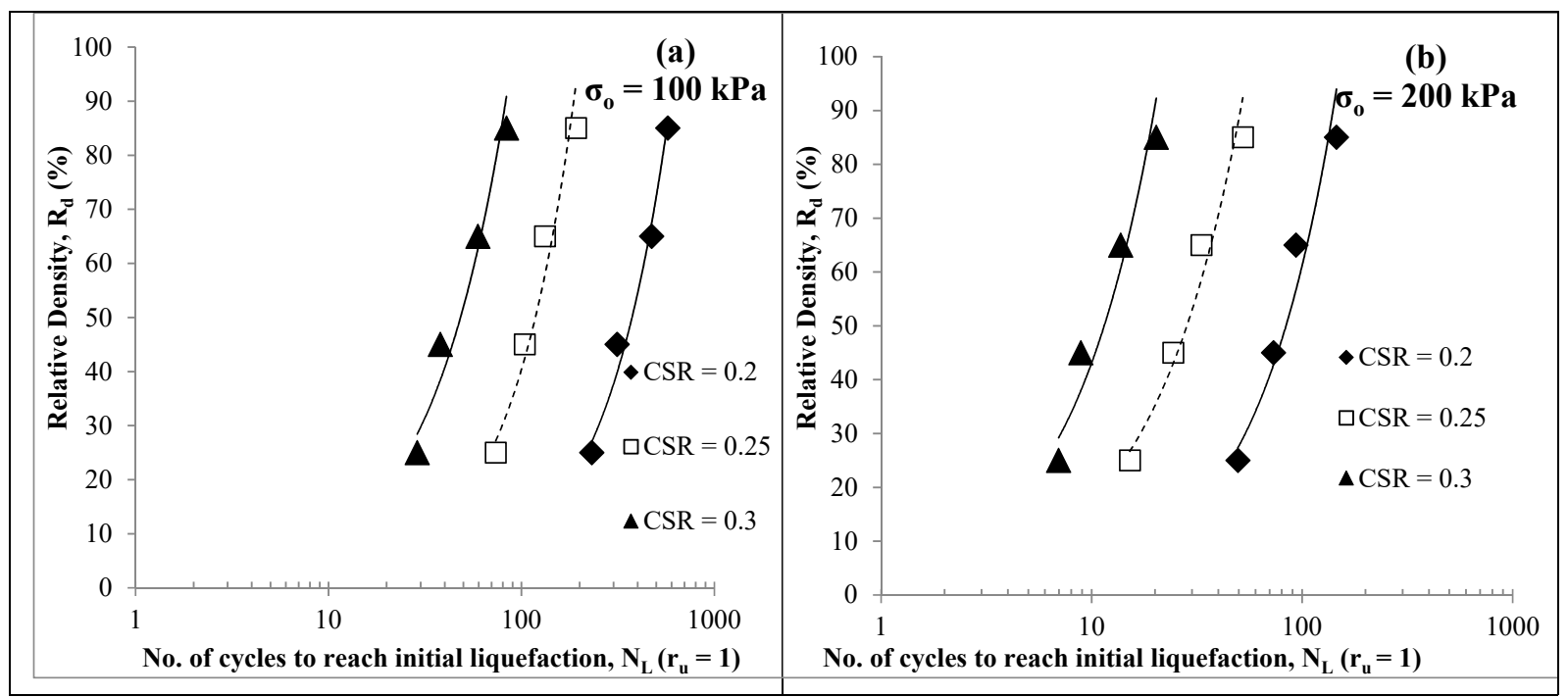

Fig. 7 Effect of relative density on number of cycles to liquefy for different cyclic stress ratios at (a) $\sigma_{\mathrm{o}}=100 \mathrm{kPa}$ and at (b) $\sigma_{\mathrm{o}}=200 \mathrm{kPa}$.

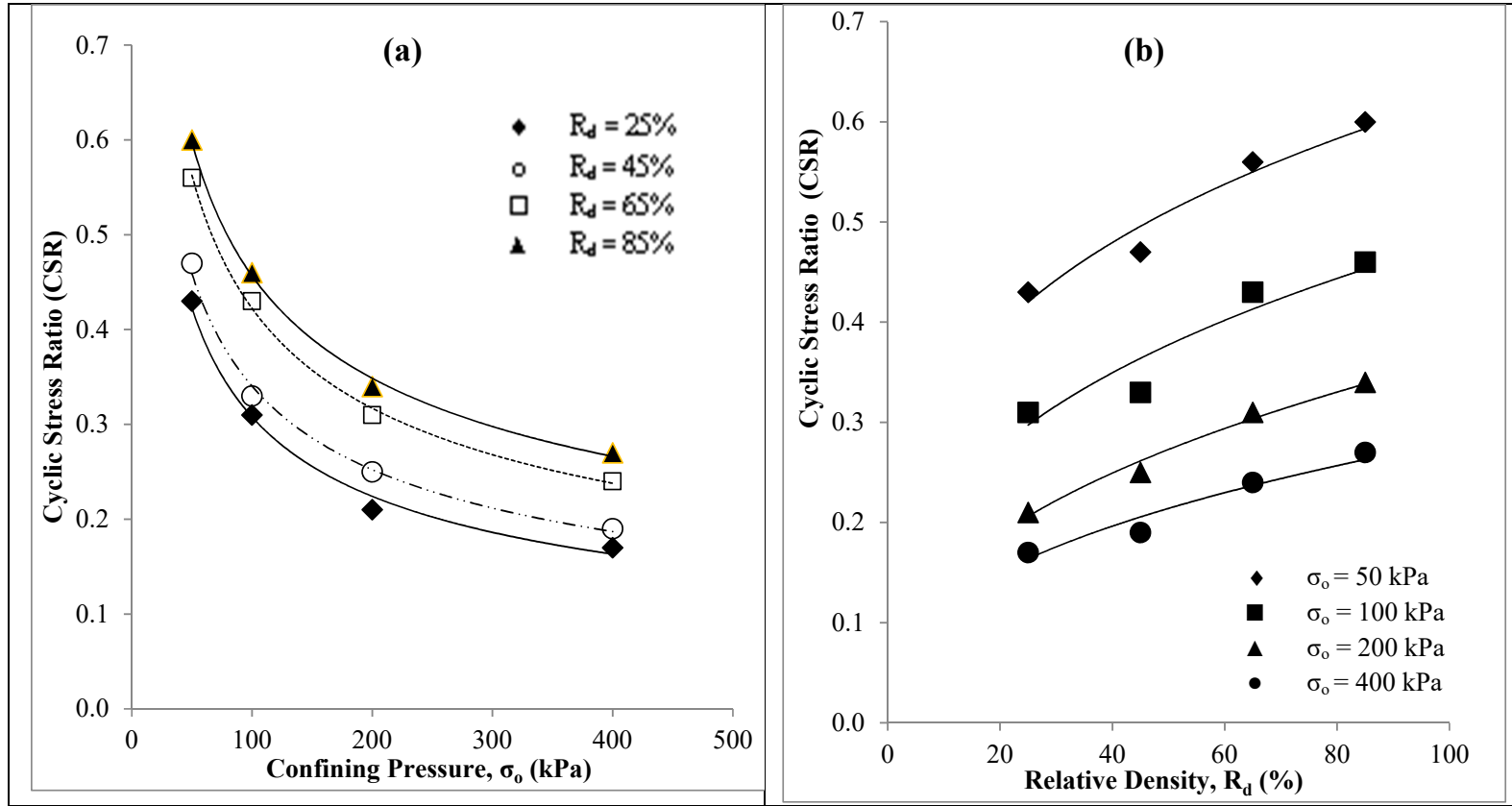

Fig. 8 Effect of (a) confining pressure and (b) relative density on the cyclic resistance (CSR) of sand for number of cycles for initial liquefaction, $\mathrm{N}_{\mathrm{L}}=15$.

cycles required to liquefy dense sample rather lesser number of loading cycles are required to cause initial liquefaction of loose sample at a particular selected loading amplitude (CSR) for effective confining pressure $100 \mathrm{kPa}$ (Fig. 7a) and $200 \mathrm{kPa}$ (Fig. 7b). Similar findings have been found by other researchers also (Krim et al., 2016; Salem et al., 2013; Rao and Ramana, 2010).

\subsection{REPRESENTATION OF LIQUEFACTION POTENTIAL IN TERMS OF CSR}

For better understanding the effects of effective confining pressure and density on liquefaction potential of Digha sand, a series of cyclic triaxial tests have been performed to determine cyclic stress ratio which causes initial liquefaction (development of excess pore water pressure ratio, $\mathrm{r}_{\mathrm{u}}=1$ ) at 15 number of loading cycles (Krim et al., 2016) and the observed cyclic stress ratio value can be presented as cyclic strength of soil. In this regard the effect of density and effective confining pressure on cyclic strength of sand (represented in terms of CSR) has been illustrated in Figure 8a (effect of effective confining pressure) and Figure $8 b$ (effect of density) at $\mathrm{N}_{\mathrm{L}}=15$. It has been observed that the rate of change of cyclic stress ratio of sand (rate of decrease) is quite higher for change of effective confining pressure rather than change of relative density (rate of increase). This phenomenon signifies that liquefaction potential of sand influences greater by change of confining pressure rather than density. 


\subsection{CORRELATION BETWEEN CSR WITH NUMBER OF CYCLES FOR LIQUEFACTION, EFFECTIVE CONFINING PRESSURE AND DENSITY OF $S A N D$}

Test results obtained from 64 cyclic triaxial tests conducted at sinusoidal loading frequency of $1 \mathrm{~Hz}$. From the test data (Fig. 5) linear regression analysis has been done. The relative density of the soil has been introduced as void ratio function $\mathrm{f}(\mathrm{e})=1 /\left(0.3+0.7 \mathrm{e}^{2}\right)$, where $\mathrm{e}$ is the void ratio of soil. So a correlation has been obtained between cyclic strength of soil (CSR), number of cycles to liquefy $\left(\mathrm{N}_{\mathrm{L}}\right)$, effective confining pressure $\left(\sigma_{o}\right)$ and relative density of soil (in terms of void ratio function, $f(e)$ ). Previously, this type of correlation has been provided by Rad and Clough (1982), Chattaraj and Sengupta (2016) in Equation 1, where cyclic strength of soil (CSR) is a function of $\mathrm{N}_{\mathrm{L}}$ and the multiplying constant, ' $a$ ' and power constant, ' $b$ ' depend on relative density of soil. A new correlation has been provided by linear regression by Salem et al. (2013) in Equation 5.

$C R R=0.6418\left(\frac{R_{d}^{0.55}}{\sigma_{\mathrm{o}}}\right)^{0.287}$

In this equation the term CRR has been proposed by Salem et al. (2013) as Cyclic Resistance Ratio of soil which can be defined as the CSR required to cause initial liquefaction of soil in 20 number of cyclic loading in stress controlled cyclic triaxial test. In this correlation it has been considered that the liquefaction will occur only at 20 numbers of loading cycles. But in all the cases of earthquake, liquefaction will not certainly happen at 20 numbers of cycles always. Liquefaction may occur at any number of loading cycles.

A new correlation of CSR of coastal Digha sand has been established by considering all the parameters i.e. number of loading cycles $\left(\mathrm{N}_{\mathrm{L}}\right)$, effective confining pressure $\left(\sigma_{0}\right)$, relative density $(\mathrm{f}(\mathrm{e}))$ and it has been given in Equation 6. The parameter, frequency has been excluded from this correlation, as it has been found frequency does not significantly affect cyclic strength of soil during liquefaction.

$C S R=\frac{0.52}{N_{L}{ }^{0.2}} \times\left(\frac{\sigma_{\mathrm{o}}}{\mathrm{P}_{\mathrm{a}}}\right)^{-0.425} \times \frac{1}{\left(0.3+0.7 e^{2}\right)^{0.837}}$

It has been found the coefficient of determination $\left(\mathrm{R}^{2}\right)$ is 0.96. In Equation 6 the term $P_{a}$ is the atmospheric pressure in $\mathrm{kPa}$ (same unit of effective confining pressure, $\sigma_{\mathrm{o}}$ ). This constant $\mathrm{P}_{\mathrm{a}}$ has been introduced to make the right hand side of the equation unit less. As the left hand side of Equation 6 is cyclic stress ratio, a unit less quantity, so it is required to represent the right hand side in unit less also. As $\mathrm{N}_{\mathrm{L}}$ and void ratio, e are both unit less terms, it is required to represent effective confining pressure, $\sigma_{o}$ in unit less term. So the effective confining pressure has been divided by atmospheric pressure to make unit less quantity, provided $\sigma_{o}$ and $\mathrm{P}_{\mathrm{a}}$ both are in same unit. So it can be stated that this equation as Equation 6 is dimensionally correct, so it can be used in any unit system and can be used within the effective confining pressure range from 50 to $400 \mathrm{kPa}$. This equation gives better prediction for determination of cyclic strength of soil by varying any input parameters (density, confining pressure and number of failure cycles). The advantage of this equation is that this model predicts the cyclic strength of sand at any number of failure cycles and in this correlation the density of sand has been introduced as field void ratio or existing void ratio of the soil in the field. So using this correlation there is no need of performing relative density test of sand (rather than Equation 5 by Salem et al. (2013) and Equation 1 by Chattaraj and Sengupta (2016). By collecting the soil sample from the field and by calculating field void ratio of sand, one can directly use the new proposed correlation to determine the cyclic strength of sand.

\subsection{VALIDATION OF THE PROPOSED CORRELATION}

It has been established that cyclic stress ratio (CSR) value of Digha sand depends on number of cycles to liquefy, effective confining pressure and relative density. Based on the experimental results a new correlation (Eqn. 6) of CSR of coastal Digha sand has been established by considering all the parameters. For better understanding the deviation of the observed experimental results of CSR value from calculated CSR value (by using Eqn. 6), the number of cycles to liquefy $\left(\mathrm{N}_{\mathrm{L}}\right)$ has been fixed as 15 .

By changing the relative density $25 \%, 45 \%$, $65 \%$ and $85 \%$ and for each relative density of sand changing the effective confining pressure $50 \mathrm{kPa}$, $100 \mathrm{kPa}, 200 \mathrm{kPa}$ and $400 \mathrm{kPa}$ total 16 experiments have performed to obtain the cyclic stress ratio value of sand which has been liquefied at number of cycles, $\mathrm{N}_{\mathrm{L}}=15$.

These total 16 experimental test results have been plotted in Figure $8 \mathrm{a}$ and Figure $8 \mathrm{~b}$. If the measured CSR value would be equal to predicted CSR value, then all the point would lie on a straight line passing through the origin and making an angle equal to $45^{\circ}$ with the horizontal. This hypothetical line has been drawn in Figure 9 by a straight line passing through the origin $(0,0)$. Any point lying on the hypothetical line would signify that for that point measured cyclic stress ratio value equals to predicted cyclic stress ratio value.

So in Figure 9, the plot of all the points (denoted by circle) along with the hypothetical straight line passing through the origin signifies the deviation of observed cyclic stress ratio from hypothetical straight line. The higher distance of a point from the hypothetical straight line, indicates the greater deviation of the measured test result from the predicted cyclic stress ratio.s in Figure 9, all the sixteen experimental data points are lying very close to the hypothetical straight line, this indicates that the proposed correlationship approximate the observed CSR value very closely. So it can be stated that this proposed correlation can be used directly to estimate the cyclic strength of Digha sand. 


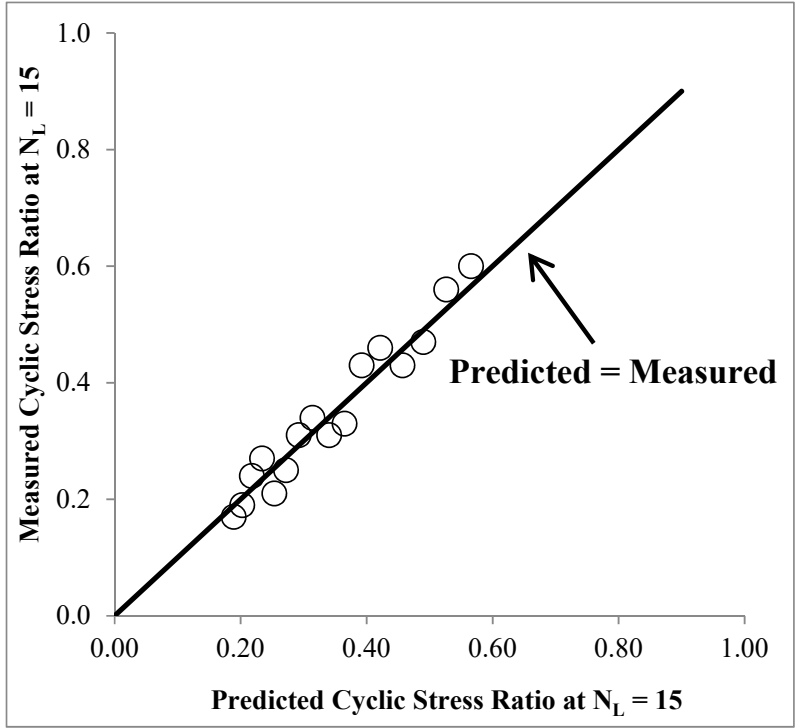

Fig. 9 Comparison of observed cyclic strength value form cyclic triaxial test with predicted cyclic strength value of Digha sand which induces liquefaction after 15 cycles.

\subsection{LIMITATION OF THE PROPOSED CORRELATION}

The new correlation proposed in this paper based on the experimental observations of stress controlled dynamic tests of coastal Digha sand has the following limitations:

i) As the sand skeleton structure, its grain size distribution, mineral constituents, size and shape of the sand particles can be found different at different locations, so it can be stated that this new correlation is valid quite well for those types of coastal sands which have the soil grain size distribution and skeleton structure similar to Digha sand.

ii) It has not been clearly understood that at very low effective confining pressure (when $\sigma_{0}$ quite less than $50 \mathrm{kPa}$ ) this correlation is valid or not.

\subsection{MAXIMUM SHEAR MODULUS, GMAX OF DIGHA SAND FROM BENDER ELEMENT TEST}

Bender element test has been performed to determine maximum shear modulus, $\mathrm{G}_{\max }$ on coastal Digha sand by varying relative density from $25 \%$ to $85 \%$ and for each density effective confining pressure has been varied from $50 \mathrm{kPa}$ to $400 \mathrm{kPa}$. Bender element tests were conducted by inducing a singlepulse sinusoidal input signal with amplitude of $14 \mathrm{~V}$ and a frequency of $5 \mathrm{kHz}$. A minimum of 10 output signals were stacked for each Bender element test and then averaged to minimize electrical noise. Figure 10a shows the Bender element input and obtained averaged output signals for a typical Bender element test conducted. At the moment of Bender element testing, the travel distance d, calculated as the tip-totip distant between Bender element source and receiver was estimated to be $96.44 \mathrm{~mm}$. The peak-topeak approach is the simplest and fastest time domain method to calculate wave travel times. It simply identifies the time span between the major first peaks of the input and output waveforms. Typical input and output signals obtained from single pulse sinusoidal bender element tests are presented in Figure 10a, as well as the identified first and second picks necessary to calculate the wave travel times.

By determining the travel time of shear wave velocity through the soil sample the velocity of shear wave, $v_{s}$ has been determined using Equation 2 and the $\mathrm{G}_{\max }$ has been calculated using Equation 3. Figure 10b illustrates the 16 experimental results of Digha sand from bender element test. It has been found that $G_{\max }$ value increases with effective confining pressure and also $G_{\max }$ increases with relative density. It has been observed that at lower effective confining pressure $(50 \mathrm{kPa})$ the difference between $\mathrm{G}_{\max }$ values (at different relative density) are lower, but with increase of effective confining pressure the difference between $\mathrm{G}_{\max }$ value (at different relative density) are increasing. So it can be concluded that $\mathrm{G}_{\max }$ value of soil is affected greatly with increase of effective confining pressure. Similar trend has been observed on experimental results on Kasai river sand by performing resonant column test (Chattaraj and Sengupta, 2016) and similar conclusion has been drawn by Dobry and Vucetic (1987) while investigating effect of confining pressure on maximum shear modulus. Due to increase in effective confining pressure the cyclic stiffness of the sand increases. Due to increase in cyclic stiffness, the maximum shear modulus of sand has been increased with increase in effective confining pressure.

In this test program of bender element test, if $d$ is the distance between the transmitter and receiver of bender element, $\lambda$ is the wavelength of the input signal then $d / \lambda$ represents the number of wave lengths that occur between the bender element transmitter and receiver and which control the shape of the received signal. For low values of $\mathrm{d} / \lambda$ there is an initial downward deflection of the trace before the shear wave arrives. For high values of $d / \lambda$ the near field effect is almost absent. So in this entire experimental procedure the input frequency has been taken as $16.8 \mathrm{kHz}$ and the value of $\mathrm{d} / \lambda$ has been taken as 8 . The input and output parameters from the bender element test has been given in Table 2 .

\subsection{CORRELATION BETWEEN MAXIMUM SHEAR MODULUS AND CYCLIC STRESS RATIO}

From the experimental results of Digha sand it has been found that the maximum shear modulus, $G_{\max }$ (from bender element test) depends on effective confining pressure and relative density (Fig. 10) and cyclic strength of sand, CSR (from cyclic triaxial test) also depend on relative density and effective confining pressure (Fig. 8), in addition number of cycles to liquefy. In this regard, at attempt has been done to correlate the $\mathrm{G}_{\max }$ with CSR at a particular failure cycle, $\mathrm{N}_{\mathrm{L}}$. 

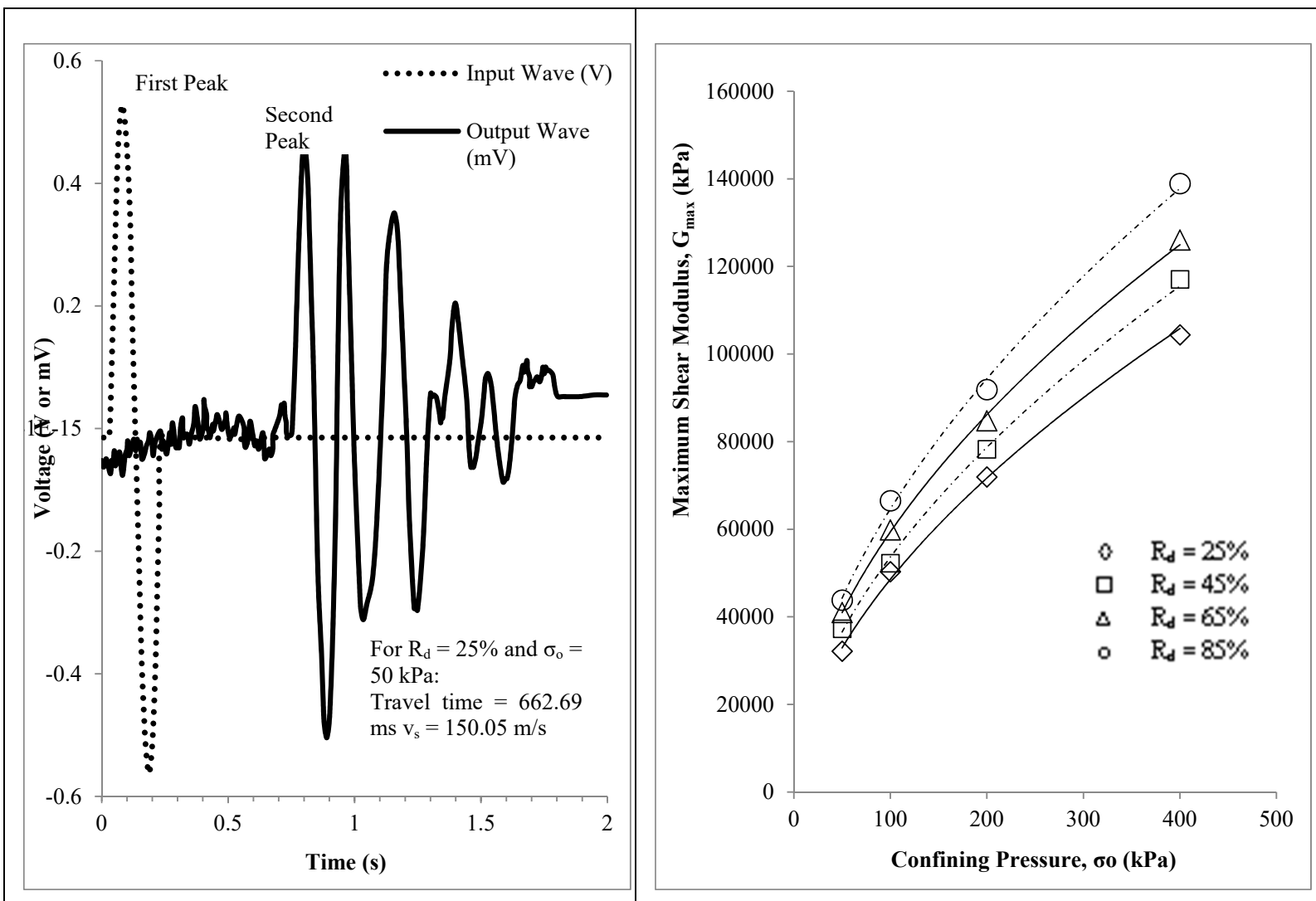

Fig. 10a Typical response curve of input and output wave from the bender element test. $\sigma_{\mathrm{o}}=50$ to $400 \mathrm{kPa}$ with $\mathrm{R}_{\mathrm{d}}=25$ to $85 \%$ from Bender Element Test.

Table $2 \mathrm{G}_{\max }$ predicted from shear wave velocity.

\begin{tabular}{cccccc}
\hline $\begin{array}{c}\text { Frequency } \\
(\mathrm{kHz})\end{array}$ & $\mathrm{d} / \lambda$ & $\begin{array}{c}\text { Predicted arrival } \\
\text { time }(\mathrm{ms})\end{array}$ & $\mathrm{v}_{\mathrm{s}}(\mathrm{m} / \mathrm{s})$ & $\begin{array}{c}\text { Density, } \gamma \\
\left(\mathrm{kg} / \mathrm{m}^{3}\right)\end{array}$ & $\begin{array}{c}\text { Effective confining } \\
\text { pressure, } \sigma_{\mathrm{o}}(\mathrm{kPa})\end{array}$ \\
\hline 16.8 & 8 & 642.69 & 150.06 & 1426.71 & 50 \\
16.8 & 8 & 513.71 & 187.73 & 1426.71 & 100 \\
16.8 & 8 & 429.53 & 224.53 & 1426.71 & 200 \\
16.8 & 8 & 356.57 & 270.46 & 1426.71 & 400 \\
16.8 & 8 & 605.81 & 159.19 & 1470.85 & 50 \\
16.8 & 8 & 511.81 & 188.43 & 1470.85 & 100 \\
16.8 & 8 & 418.24 & 230.59 & 1470.85 & 200 \\
16.8 & 8 & 341.89 & 282.08 & 1470.85 & 400 \\
16.8 & 8 & 586.92 & 164.32 & 1517.77 & 50 \\
16.8 & 8 & 485.70 & 198.56 & 1517.77 & 100 \\
16.8 & 8 & 408.14 & 236.29 & 1517.77 & 200 \\
16.8 & 8 & 334.69 & 288.15 & 1517.77 & 400 \\
16.8 & 8 & 576.85 & 167.18 & 1567.81 & 50 \\
16.8 & 8 & 468.25 & 205.96 & 1567.81 & 100 \\
16.8 & 8 & 398.35 & 242.10 & 1567.81 & 200 \\
16.8 & 8 & 323.97 & 297.68 & 1567.81 & 400 \\
\hline
\end{tabular}

The first attempt to make this correlation has been proposed by De Alba et al. (1984) on Monterey No. 0 sand and Dover sand. As the term cyclic stress ratio is dimensionless and $\mathrm{G}_{\max }$ has a unit of $\mathrm{kPa}$, so to make the term dimensionless $\mathrm{G}_{\max }$ has been divided by effective confining pressure, $\sigma_{\mathrm{o}}$ by De Alba et al. (1984). But this correlation has been established for number of failure cycles, $\mathrm{N}_{\mathrm{L}}=10$ only. At other values of $\mathrm{N}_{\mathrm{L}}$ whether this correlation would be valid was not clearly established. This drawback has been overcome by Chattaraj and Sengupta (2016), where correlation between CSR and $\mathrm{G}_{\max }$ has been established at any number of failure cycles (i.e. $\mathrm{N}_{\mathrm{L}}=5,10$ and 20) by performing cyclic triaxial test and resonant column test on Kasai river sand. This correlation is more realistic than De Alba et al. (1984) as $G_{\max }$ has been 


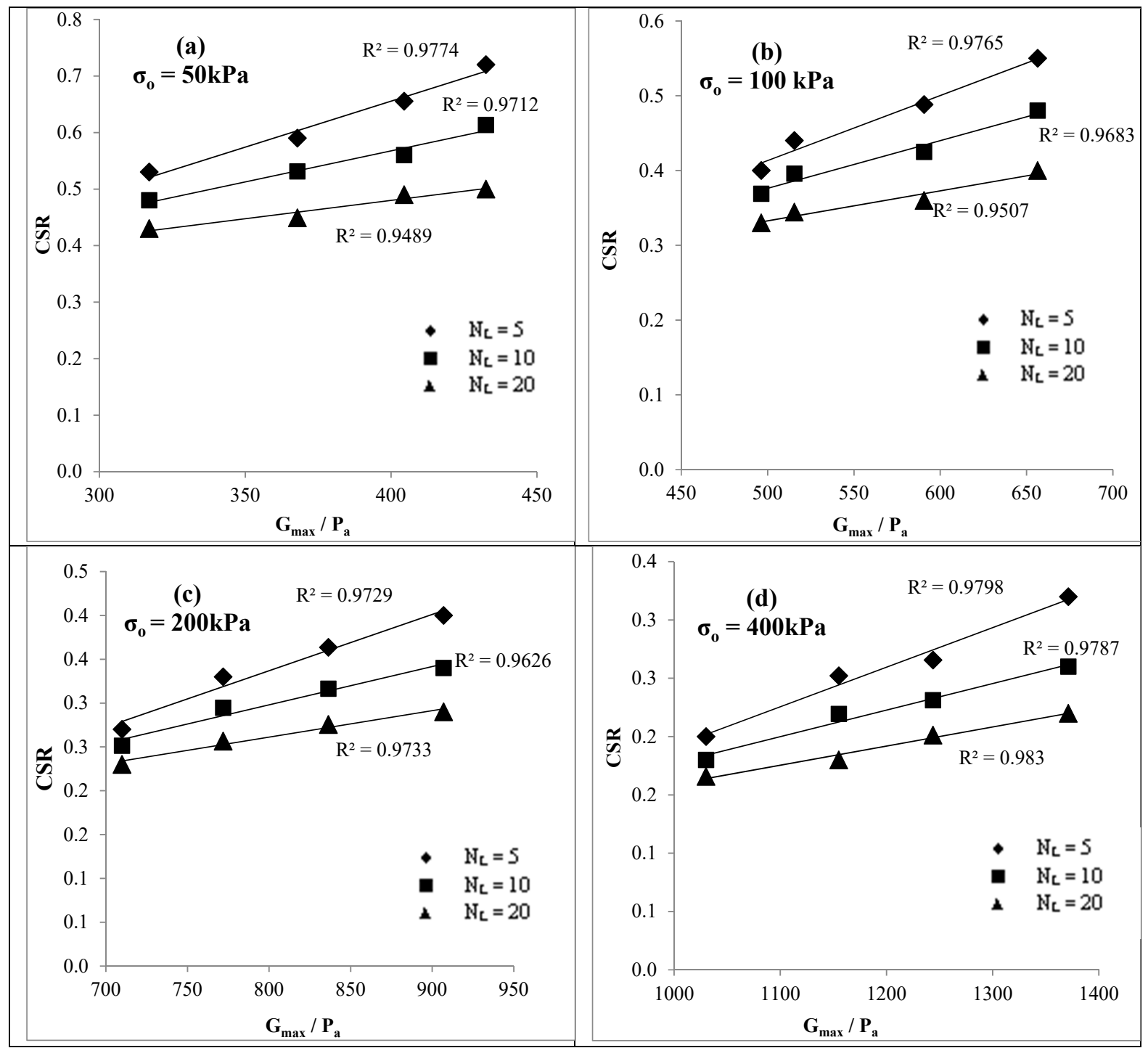

Fig. 11 Correlation between cyclic resistance of sand with maximum shear modulus at number of failure cycles 5,10 and 20 at (a) $\sigma_{\mathrm{o}}=50 \mathrm{kPa}(\mathrm{b}) \sigma_{\mathrm{o}}=100 \mathrm{kPa}$ (c) $\sigma_{\mathrm{o}}=200 \mathrm{kPa}(\mathrm{d}) \sigma_{\mathrm{o}}=400 \mathrm{kPa}$.

represented as $G_{\max } / P_{a}$ term, where $P_{a}$ is atmospheric in the same unit of $G_{\max }$. But the drawback in the correlation proposed by Chattaraj and Sengupta (2016), was the cyclic triaxial test has been performed only at effective confining pressure $=100 \mathrm{kPa}$. So whether there exists good correlation between CSR and $\mathrm{G}_{\max } / \mathrm{P}_{\mathrm{a}}$ at any value of effective confining pressure was not clearly mentioned. This drawback has been overcome in the experimental results of coastal Digha sand in this present study.

From Figure 11 it has been well established that a good correlation between $\mathrm{CSR}$ and $\mathrm{G}_{\max } / \mathrm{P}_{\mathrm{a}}$ exist at any number of failure cycles at any value of effective confining pressure. For better understanding a comparative study of test results of Digha sand (present study) by marker with solid fill and Kasai sand (Chattaraj and Sengupta, 2016) by marker with no fill has been given at $\sigma_{\mathrm{o}}=100 \mathrm{kPa}$ in Figure 12 . Figure 11 illustrates that at lower value of $G_{\max }$ of Digha sand the cyclic stress ratio values fall within a shorter range but at higher values of $G_{\max }$ the differences of cyclic stress ratio values increases. But in all the cases Figure 11a to Figure 11d it has been found that the coefficient of determination $\left(\mathrm{R}^{2}\right)$ is more than 0.94 , which indicates that a well correlation exists between cyclic strength of soil with its maximum shear modulus at any number of failure cycles for a particular density and effective confining pressure.

In this present study for determination of liquefaction potential of coastal Digha sand, it might be questionable that what is the reason behind determining maximum shear modulus of Digha soil, as the objective of this present study is to determine liquefaction potential and pore water pressure generation of coastal Digha sand. The answer of determining $G_{\max }$ value of Digha sand is in this present study an effort has been done to investigate all types of possible parameters which can affect the cyclic strength of coastal Digha sand (in terms of CSR). As an effort has been done by previous researchers not only frequency, density, confining pressure or number 


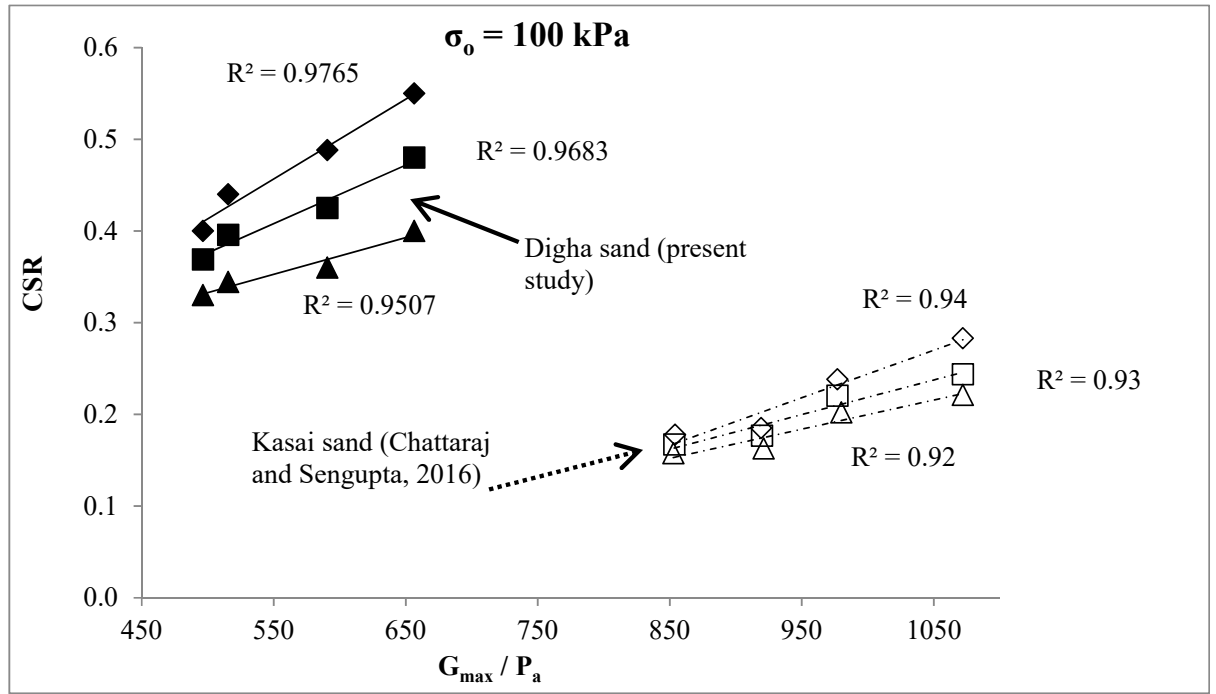

Fig. 12 Comparison of test data between correlation cyclic strength of sand with maximum shear modulus for Digha sand (present study) and Kasai sand (Chattaraj and Sengupta, 2016).

of cyclic loadings, also the maximum shear modulus influences the liquefaction potential of Digha sand. In this regard as there were some drawbacks to establish the correlation between cyclic strength and maximum shear modulus, an effort has been done to rectify those drawbacks, discussed earlier. Due to this reason determination of $\mathrm{G}_{\max }$ of Digha sand (by performing Bender element test) has become essential in this present study.

\subsection{EXCESS PORE WATER PRESSURE GENERATION DURING CYCLIC LOADING}

During cyclic loading generation of excess pore water pressure is the one of the most important phenomenon in cyclic triaxial test. During application of cyclic loadings under undrained condition excess pore water pressure builds up and when the excess pore water pressure becomes equal to effective confining pressure, the effective stress in sample become equal to zero and the sample loses it strength completely. This is termed as initial liquefaction. Figure 13a to Figure 13d show the excess pore water pressure builds up during cyclic loading. Similar kind of pore water pressure generation has been observed by Baziar et al. (2011) using hollow torsional test. Figure 13 illustrates that the generation of excess pore pressure ratio, $r_{u}$ along with cycle ratio $\left(\mathrm{N} / \mathrm{N}_{\mathrm{L}}\right)$, where $\mathrm{N}_{\mathrm{L}}$ is the number of cycles required for initial liquefaction and $\mathrm{N}$ is the number of loading cycles which vary from 0 to $\mathrm{N}_{\mathrm{L}}$. As a result the cycle ratio $\left(\mathrm{N} / \mathrm{N}_{\mathrm{L}}\right)$ varies from 0 to 1 along with variation of $r_{u}$ from 0 to 1 . It has been observed from Figure 13 that the generation of pore water pressure $\left(r_{u}\right)$ mainly depends on number of loading cycles along with cyclic strength of soil (CSR) and relative density $\left(R_{d}\right)$. Similar observation has been reported by Govindaraju (2005). The rate of generation of excess pore water pressure during cyclic loading has been found at the fastest rate at higher cyclic loading amplitude (CSR = $0.3)$ and lower relative density $\left(\mathrm{R}_{d}=25 \%\right)$ shown in Figure 13a and the rate of generation of $r_{u}$ is slowest at lower value of cyclic loading amplitude $(\mathrm{CSR}=0.2)$ and higher relative density $\left(\mathrm{R}_{\mathrm{d}}=85 \%\right)$ shown in Figure $13 \mathrm{~d}$. By analyzing the nature of pore pressure generation curve (Fig. 13a to Fig. 13d) it can be concluded that at the initial few cycles, the pore water pressure generates at a faster rate (approximately upto $r_{u}=0.5$ ) and eventually it become stable with slower rate as considerable amount of pore water pressure builds up. But at the last few cycles, the pore water pressure shoots up rapidly due to the large shear deformation in the soil and leads to initialization of the liquefaction. At this stage, the effective stress in the sand becomes zero and initial liquefaction initiates.

From the nature of all the curves of excess pore water pressure generation a new pore pressure generation model has been proposed in Equation 7.

$r_{u}=0.5+\frac{1}{\pi} \sin ^{-1}\left[\left\{\ln \left(\frac{N}{N_{L}}\right)^{\beta}\right\}+1\right]$

where, the power term ' $\beta$ ' depends on cyclic strength of soil (CSR) and relative density of soil, represented in terms of void ratio function $\mathrm{f}(\mathrm{e})$. So the power term $\beta$ can be expressed as in Equation 8 .

$\beta=1.86 \times(C S R)^{0.8} \times[f(e)]^{0.2}$

where, the void ratio function $\mathrm{f}(\mathrm{e})$ has been expressed by Eqn 9 .

$f(e)=0.5022 \times\left[\frac{(2.17-e)^{2}}{1+e}\right]^{3.4785}$

whereas, e is the field void ratio of Digha sand.

From this pore pressure generation model it is clear that the excess pore water pressure during cyclic loading primarily depends on number of loading cycles, but the rate of pore water pressure generation (faster rate or slower rate) depends on the power term 


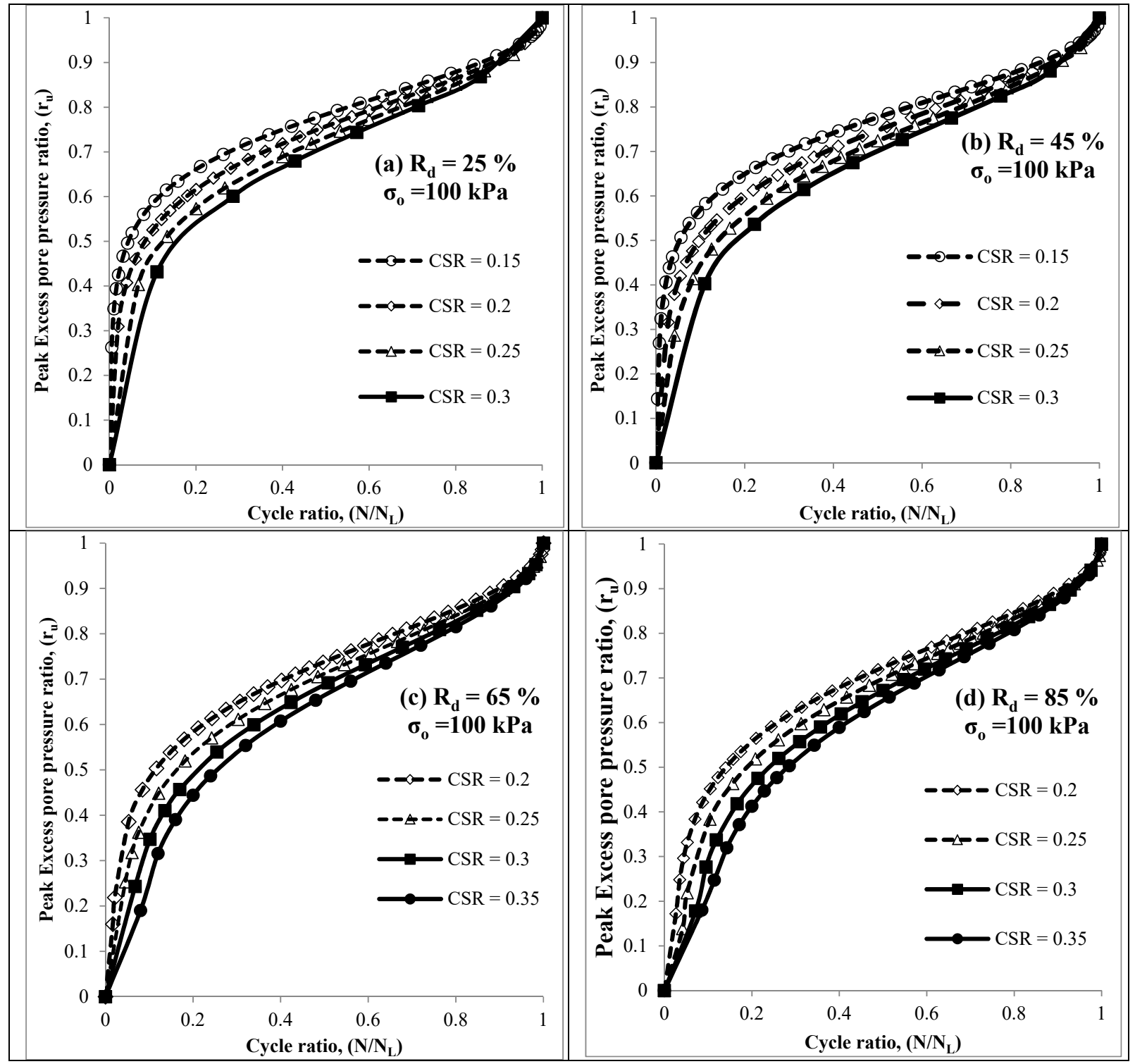

Fig. 13 Excess pore water pressure generation in Digha sand with cycle ratio at different cyclic stress ratio at (a) $R_{d}=25 \%$; (b) $R_{d}=45 \%$; (c) $R_{d}=65 \%$; (d) $R_{d}=85 \%$.

' $\beta$ ', where, Equation 8 illustrates that rate of excess pore water pressure generation depends more on amplitude of cyclic loading, rather than density.

\subsection{UPPER BOUND AND LOWER BOUND CURVE OF EXCESS PORE WATER PRESSURE GENERATION AND ITS VALIDATION}

By analyzing the numerical model of excess pore water pressure generation an upper bound and lower bound curve of excess pore water pressure generation has been introduced in this paper, shown in Figure 14. It has been shown in Figure 14 that all the experimental results of excess pore water pressure generation fall within the two limiting curves, which illustrates that for any type coastal sand having similar grain size character and physical properties like coastal Digha sand the pore water pressure generation will fall within the two limiting boundary curves shown in Figure 14. The study of excess pore water pressure generation has been done by other researchers also and several researchers have proposed different kinds of upper bound and lower bound curves of excess pore pressure generation (Talaganov, 1996; Dobry, 1985; Baziar et al., 2011; Lee and Albaisa, 1974; EL Hosri et al., 1984; Seed et al., 1976). The boundary curves have been introduced by Talaganov (1996) from the strain controlled test, in terms of by excess pore pressure ratio $\left(\mathrm{r}_{\mathrm{u}}\right)$ versus cycle ratio $\left(\mathrm{N} / \mathrm{N}_{\mathrm{L}}\right)$, which trend has been followed in the present study of Digha sand. To validate the newly proposed boundary curves of pore pressure generation comparative study has been done on the previous existing boundary curves by Talaganov (1996) and the newly proposed boundary curves from present study, shown in Figure 14. The boundary curves (Fig. 14) of Talaganov (1996) has been presented by grey colour (dotted grey line - lower bound and solid grey line upper bound) and proposed boundary curves of 


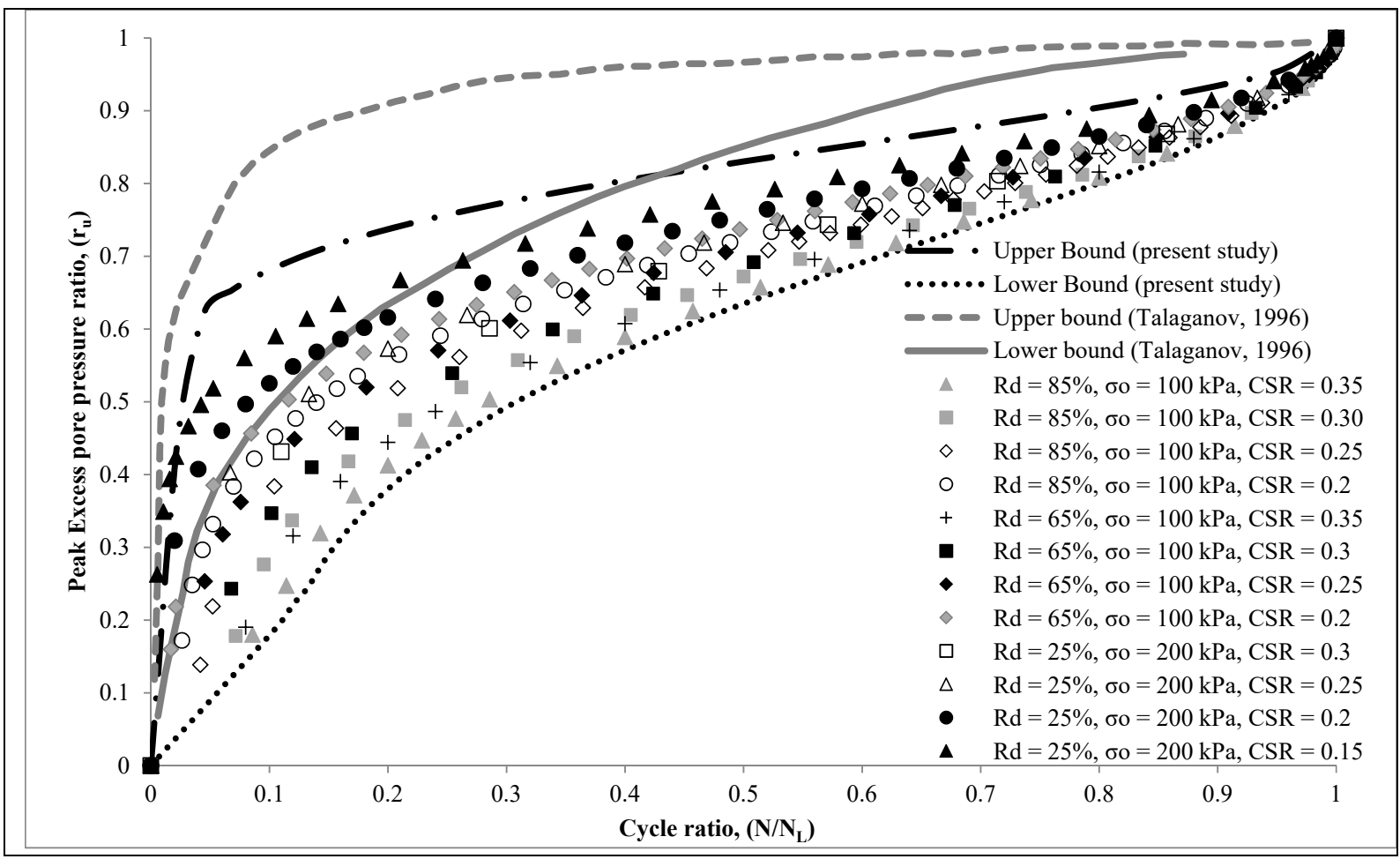

Fig. 14 Proposed upper bound and lower bound of excess pore water pressure generation of Digha sand during cyclic triaxial test along with experimental test results along with proposed upper bound and lower bound curve by Talaganov (1996).

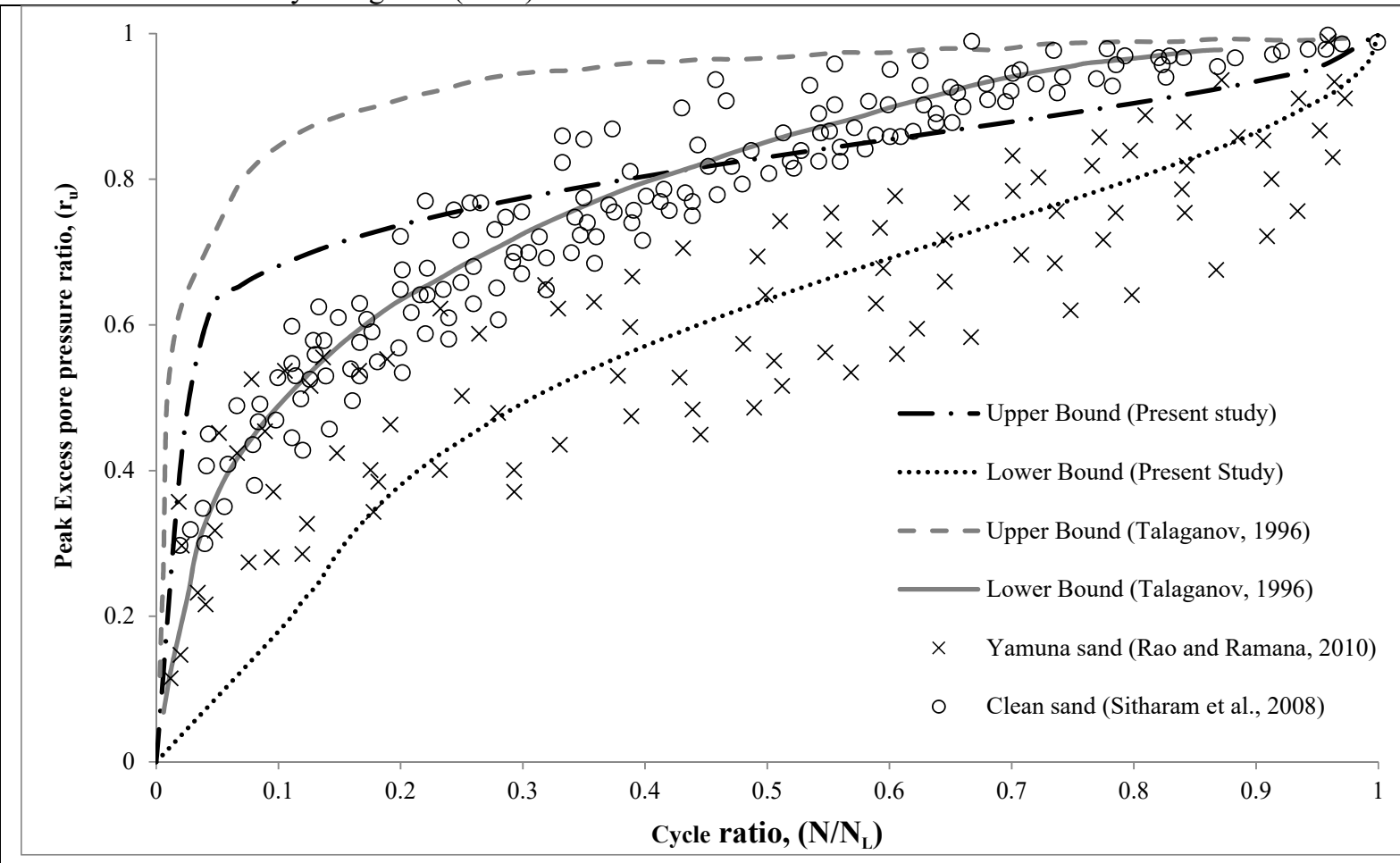

Fig. 15 Comparative study of proposed upper bound and lower bound curve of excess pre water pressure generation of coastal sand in present study along with proposed upper bound and lower bound curve by Talaganov (1996) along with experimental test results of other sands by cyclic triaxial test.

present study has been represented by black colour (solid black line - upper bound and dotted black line lower bound). It has been observed in Figure 14 that where almost all the points are lying inside the boundary curves proposed in this present study, but a huge number of pore pressure generation points are lying outside the boundary curves proposed by Talaganov (1996). 
Table 3 Comparative study of physical properties of three types of sands.

\begin{tabular}{lcccccc}
\hline \multicolumn{1}{c}{ Type of Sand } & $\mathrm{G}_{\mathrm{s}}$ & $\mathrm{D}_{10}(\mathrm{~mm})$ & $\mathrm{D}_{50}(\mathrm{~mm})$ & \multicolumn{1}{c}{$\mathrm{C}_{\mathrm{u}}$} & \multicolumn{1}{c}{$\mathrm{e}_{\max }$} & $\mathrm{e}_{\min }$ \\
\hline Digha sand (present study) & 2.72 & 0.123 & 0.26 & 2.44 & 0.978 & 0.692 \\
Clean Sand (Sitharam et al., 2008) & 2.65 & 0.077 & 0.3 & 3.57 & 0.69 & 0.44 \\
Yamuna Sand (Rao and Ramana, 2010) & 2.66 & 0.11 & 0.21 & 2 & 1.015 & 0.546 \\
\hline
\end{tabular}

A comparative study of pore water pressure generation from cyclic triaxial test results of other researchers have been represented in Figure 15 along with upper and lower boundary curves (newly proposed and previously proposed by Talaganov (1996). Sitharam et al. (2008) has done strain controlled cyclic triaxial tests on clean sand by varying relative density 30 to $70 \%$ and effective confining pressure 50 to $200 \mathrm{kPa}$. All the clean sand by Sitharam et al. (2008) data has been shown in Figure 15 by marker with 'circle'. Rao and Ramana (2010) have done stress controlled cyclic triaxial test on Yamuna sand by varying relative density 30 to $70 \%$ and effective confining pressure $106 \pm 1 \mathrm{kPa}$. All the Yamuna sand data has been presented by marker with 'cross' in Figure 15. It has been observed from Figure 15 that very few data of excess pore water pressure generation are lying within the boundaries proposed by Talaganov (1996), whereas more number of data lie within the newly proposed boundary obtained from coastal Digha sand.

A comparative study of physical properties of all the three sands taken i.e. Digha sand (present study); Yamuna sand (Rao and Ramana, 2010) and Clean sand (Sitharam et al., 2008) have been provided in Table 3. So from Table 3 it is clear that those types of sand having grain size distribution nearer to coastal Digha sand, in that case there is very high chance that the excess pore water pressure generation during earthquake will fall within the proposed upper and lower boundaries.

\section{CONCLUSION}

A series of stress controlled cyclic triaxial tests have been carried out on coastal sand at Digha region located at eastern coast of India. All the tests have been performed on saturated sands by preparing the specimens by dry deposition methods by varying cyclic stress ratios, frequencies, soil density, effective confining pressures and number of loading cycles for initial liquefaction. Bender element tests have been done on the same sand at four density and four confining pressures. From the experimental results the following conclusions have drawn on coastal sand at Digha region:

1. Frequency of loading cycles does not affect significantly the number of cycles for initial liquefaction of sand.

2. The cyclic strength of sand has been identified as cyclic stress ratio which reduces as the number of cycles for initial liquefaction increases for a particular density and a particular confining pressure.

3. For a particular cyclic stress ratio the liquefaction potential of sand increases with increase in relative density but the liquefaction potential decreases with increase in effective confining pressure.

4. By selecting a particular number of loading cycles for initial liquefaction of sand $\left(\mathrm{N}_{\mathrm{L}}=15\right)$ it has been observed that cyclic strength of sand (cyclic stress ratio) increases with increase in relative density but reduces with increase in effective confining pressure. But the rate of change of cyclic stress ratio of sand (slope of the curve) is quite higher for change of effective confining pressure rather than change of relative density, which signifies that liquefaction potential of sand influences greater by change of confining pressure with respect to change in density.

5. A new empirical correlation between cyclic stress ratio and change of effective confining pressure, sand density and number of loading cycles for initial liquefaction of coastal Digha sand has been developed by regression analysis. The test results have been closely approximate the predicted results by using the new correlation and can be used at any system of units.

6. From Bender element tests the maximum shear modulus at different soil density and confining pressure has been determined and its correlation with cyclic stress ratio of sand at any number of cycles for initial liquefaction has been investigated. A high correlation coefficient indicates that there is a well linear correlation exists between maximum shear modulus and cyclic stress ratio at any relative density and at any confining pressure of sand for any number of cycles causing initial liquefaction.

7. It has been observed that at lower value of $\mathrm{G}_{\max }$ of Digha sand the cyclic stress ratio values fall within a shorter range but with increase in values of $\mathrm{G}_{\max }$ the differences of cyclic stress ratio values increases. Higher the $\mathrm{G}_{\max }$ value, greater the differences between of cyclic stress ratio values at different number of cycles for a particular density and confining pressure.

8. A new pore pressure generation model has been introduced for coastal Digha sand, where it has been found that the rate of generation of excess pore water pressure depends on cyclic stress ratio value applied to the soil and the density of sand. Upper bound and lower bound curves of excess 
pore excess pore water pressure generation have been introduced in this study. It has been found that the test results fall within the range of two boundary curves. The newly proposed boundary curves have been compared by boundary curves proposed by Talaganov (1996) and cyclic triaxial test results of other sands by other researchers have been compared with the newly proposed boundary curves.

\section{ACKNOWLEDGEMENT}

The authors are highly thankful to Civil Engineering Department of Jadavpur University for providing the opportunity to organize this research project along with arrangement of soil sample from Digha region and to provide permission to access the Soil Mechanics Laboratory of Civil Engineering Department of Jadavpur University to conduct several experimental works in the laboratory along with supporting manpower.

\section{REFERENCES}

Akhila, M., Rangaswamy, K. and Sankar, N.: 2019, Undrained response and liquefaction resistance of sand-silt mixtures. Geotech. Geol. Eng., 37, 27292745. DOI: $10.1007 / \mathrm{s} 10706-018-00790-0$

ASTM D2487: 2006, Standard practice for classification of soils for engineering purposes (unified soil classification system). West Conshohocken. PA: ASTM International.

ASTM D5311-11: 2013, Standard test method for load controlled cyclic triaxial strength of soil. West Conshohocken, Pennsylvania, USA. American Society of Testing and Materials.

Baziar, M.H., Shahnazari, H. and Sharafi, H.: 2011, A laboratory study on the pore pressure generation model for Firouzkooh silty sands using hollow torsional test. Int. J. Civ. Eng., 9, 2, 126 - 134.

Biswas, A. and Das, H.: 2014, Characteristics of surface soil around Digha coastal region of West Bengal. IOSR IJHHS, 19, 7, ver. III, 25-30.

Castro, G. and Poulos, J.: 1977, Factors affecting liquefaction and cyclic mobility. ASCE J. Geotech. Eng., 103, 6, 501-16.

Chattaraj, R. and Sengupta, A.: 2016, Liquefaction potential and strain dependent dynamic properties of Kasai River sand. Soil Dyn. Earthq. Eng., 90, 467-75. DOI: 10.1016/j.soildyn.2016.07.023

Dalal, S.S. and Sahu R.B.: 2011, Evaluation of Cpt Friction Ratio of some soils of West Bengal. Indian Geotech. J., 41, 4, 206-214.

Dasgupta, S., Narula, P.L., Acharyya, S.K. and Banerjee, J. 2000, Seismotectonic atlas of India and its environs. Geological Society of India.

De Alba, P., Baldwin, K., Janoo, V., Roe, G. and Celikkol, B.: 1984, Elastic-wave velocities and liquefaction potential. Geotech. Test. J., GTJODJ, 7, 2, 77-87.

Dobry, R., Ladd, R.S., Yokel, F.Y., Chung, R.M. and Powell, D.: 1982, Prediction of pore water pressure buildup and liquefaction of sands during earthquakes by the cyclic strain method. National Bureau of Standards Building Science Series, 138, 150.
Dobry, R. And Vucetic, M.: 1987, State-of-the-art report: Dynamic properties and response of soft clay deposits. Proc. Int. Symp. on Geotechnical Engineering of Soft Soils, 2, 51-87.

El-Hosri, M.S., Biarez, M.S. and Hicher, P.Y.: 1984, Liquefaction characteristics of silty clay. Proc. 8th World Conf. Earthq. Eng., 3, San Francisco, CA, 277 84.

Evans, M.D. and Zhou, S.: 1995, Liquefaction of sandgravel composites. ASCE J. Geotech. Eng., 121, 3, 287-98. DOI: $10.1061 /(A S C E) 0733-$ 9410(1995)121:3(287)

Finn, W.D., Pickering, D.J. and Bransby, P.L.: 1971, Sand liquefaction in triaxial and simple shear tests. ASCE J. Geotech. Eng., 97, 4, 639-59.

Govindaraju, L.: 2005, Liquefaction and dynamic properties of sandy soils. Ph.D. thesis, Indian Institute of Science, Bangalore.

Hyodo, M., Hyde, A.F.L. and Aramaki, N.: 1998, Liquefaction of crushable soils. Geotechnique, 48, 4, 527-43. DOI: 10.1680/geot.1998.48.4.527

IS 1498: 1970, Classification and identification of soils for general engineering purposes. New Delhi, Bureau of Indian Standards.

IS 2720 (Part-3): 1981, Determination of specific gravityfine, medium and coarse grained soils. New Delhi, Bureau of Indian Standards.

IS 2720 (Part-14): 1983, Determination of density index of cohesionless soils. New Delhi, Bureau of Indian Standards.

Ishihara, K., Kikuchi, Y. and Tsutsumi, K.: 1983, Cyclic deformation behavior of sands under low confining pressure. Proc. $18^{\text {th }}$ Japanese National Soil Mechanics Research Meeting, JSSMFE.

Jana, A. and Bhattacharya, A.K.: 2012, Assessment of coastal erosion vulnerability around MidnapurBalasore Coast, Eastern India using integrated remote sensing and GIS techniques. J. Indian Soc. Remote Sens., 41, 675-686.

DOI: $10.1007 / \mathrm{s} 12524-012-0251-2$

Jana, A., Biswas, A., Maiti, S. and Bhattacharya, A.K.: 2013, Shoreline changes in response to sea level rise along Digha Coast, Eastern India: an analytical approach of remote sensing, GIS and statistical techniques. J. Coast. Conserv., 18. 3, 145-155. DOI: $10.1007 / \mathrm{s} 11852-013-0297-5$

Krim, A., Arab, A., Bouferra, R., Sadek, M. and Shahrour, I.: 2016, Characteristics of cyclic shear behavior of sandy soils: A laboratory study. Arab. J. Sci. Eng., 41, 3995-4005. DOI: 10.1007/s13369-016-2064-Z

Konstadinoun, M. and Georgiannou, V.N.: 2014, Prediction of pore water pressure generation leading to liquefaction under torsional cyclic loading. Soils Found., 54, 5, 993-1005.

DOI: $10.1016 /$ j.sandf.2014.09.010

Kumar, S.S., Krishna, A.M. and Dey, A.: 2017, Evaluation of dynamic properties of sandy soil at high cyclic strains. Soil Dyn. Earthq. Eng., 99, 157-167. DOI: $10.1016 /$ j.soildyn.2017.05.016

Ladd, R.S.: 1978, Preparing test specimens using under compaction. Geotech. Test. J., 1, 1, 16-23. DOI: $10.1520 / \mathrm{GTJ} 10364 \mathrm{~J}$

Lee, K.L. and A. Albaisa, A.: 1974, Earthquake induced settlements in saturated sands. J. Geotech. Eng. Div., ASCE, 100, 4, 387-406. 
Lee, K.L. and Fitton, J.A.: 1969, Factors affecting the cyclic loading strength of soils. Vibration effects of earthquakes on soils and foundations, ASTM SPT 450, 71-95. DOI: 10.1520/STP33637S

Lee, K.L. and Seed, H.B.: 1967, Cyclic stress conditions causing liquefaction of sand. J. Soil Mech. Found. Div., ASCE, 93, (SM1), 47-70.

Lin, P.S., Chang, C.W. and Chang, W.J.: 2004, Characterization of liquefaction resistance in gravelly soil: Large hammer penetration test and shear wave velocity approach. Soil Dyn. Earthq. Eng., 24, 9-10, 675-687. DOI: 10.1016/j.soildyn.2004.06.010

Maheshwari, B., Kale, S. and Kaynia, A.: 2012, Dynamic properties of Solani sand at large strains: a parametric study. Int. J. Geotech. Eng., 6, 3, 353-358. DOI: 10.3328/IJGE.2012.06.03.353-358

Mandal, M., Dandapath, P.K. and Bhushan, S.: 2013, Digha Sankarpur littoral tract A geographical case study. IJHSSI, 2, 4, 46-54.

Morioka, B.T. and Nicholson, P.G.: 2000, Evaluation of the liquefaction potential of calcareous sand. Proc. International Offshore and Polar Engineering Conference, Seattle, WA, USA, 494-500.

Peacock, W.H. and Seed H.B.: 1968, Sand liquefaction during cyclic loading simple shear conditions. J. Geotech. Eng., ASCE, 94(SM3), 689-708.

Pitchaikani, J.S., Kadharsha, K. and Mukherjee, S.: 2016, Current status of seawater quality in Digha (India), northwestern coast of the Bay of Bengal. Environ. Monit. Assess., 188, 7. DOI: $10.1007 / \mathrm{s} 10661-016-5383-3$

Porcino, D. and Diano, V.: 2016, Laboratory study on pore pressure generation and liquefaction of low-plasticity silty sandy soils during the 2012 earthquake in Italy. J. Geotech. Geoenviron. Eng., 142, 10.

DOI: 10.1061/(ASCE)GT.1943-5606.0001518

Rad, N.S., and Clough, W.G.: 1982, The influence of cementation on the static and dynamic behavior of sands Stanford, California. The John A. Blume Earthquake Engineering Center, Stanford University, Report No. 59.

Rao, C.H. and Ramana, G.V.: 2010, Characterization of cyclic strength of Yamuna Sand. Int. J. Earth Sci. Eng., $3,2,234-242$.

Salem, M., Elmamlouk, H. and Agaiby, S.: 2013, Static and cyclic behavior of North Coast calcareous sand in Egypt. Soil Dyn. Earthq. Eng., 55, 83-91. DOI: $10.1016 /$ j.soildyn.2013.09.001

Sandoval, E.A. and Pando, M.A.: 2012, Experimental assessment of the liquefaction resistance of calcareous biogenous sands. Earth Sci. Res. J., 16, 1, 55-63.

Saxena, S.K., Reddy, K.R. and Avramidis, A.S.: 1988, Liquefaction resistance of artificially cemented sand. J. Geotech. Eng., 114, 12, 1395-413.

DOI: 10.1061/(ASCE)0733-9410(1988)114:12(1395)

Seed, H.B. and Lee, K.L.: 1966, Liquefaction of saturated sands during cyclic loading. J. Soil Mech. Found. Div., 92, 6, 105-34.

Seed, H.B., Martin P.P. and Lysmer, J.: 1976, Pore water pressure change during soil liquefaction. ASCE J. Geotech. Eng. Div, 102, 4, 323-346.
Seed, H.B. and Peacock, W.H.: 1971, Test procedures for measuring soil liquefaction characteristics. ASCE J. Soil Mech. Found. Div., 97, 8, 1099-1119.

Sharma, S.S. and Ismail, M.A.: 2006, Monotonic and cyclic behaviour of two calcareous soils of different origins. ASCE J. Geotech. Geoenviron. Eng., 132, 12, 158191.

DOI: 10.1061/(ASCE)1090-0241(2006)132:12(1581)

Silver, L., Chan, K., Ladd, S., Lee, L., Tiedemann, A., Townsend, C., Valera, E. and Wilson, H.: 1976, Cyclic triaxial strength of standard test sand. ASCE J. Geotech. Eng., 102, 5, 511-523.

Sitharam, T.G. and Govindaraju, L.: 2007, Pore pressure generation in silty sands during cyclic loading. Geomech. Geoeng., 2, 4, 295-306. DOI: $10.1080 / 17486020701670460$

Sitharam, T.G., Govindaraju, L. and Murthy, B.R.S.: 2004, Evaluation of liquefaction potential and dynamic properties of Silty sand using cyclic triaxial testing. Geotech. Test. J., 27, 5, 423-429.

Sitharam, T.G., Ravishankar, B.V. and Vinod, J.S.: 2008, Liquefaction and pore water pressure generation in sand - A cyclic strain approach. J. Earthq. Tsunami, 2, 3, 227-240. DOI: 10.1142/S1793431108000396

Skempton, A.W.: 1954, The pore-pressure coefficients A and B. Geotechnique, 4, 4, 143-147. DOI: $10.1680 /$ geot.1954.4.4.143

Stedman, J.D.: 1997, Effects of confining pressure and static shear on liquefaction resistance of Fraser River. B.A.Sc. Thesis, The University of British Columbia, Canada.

Talaganov, K.V.: 1996, Stress-strain transformations and liquefaction of sands. Soil Dyn. Earthq. Eng., 15, 7, 411-418. DOI: 10.1016/0267-7261(96)00024-3

Tsuchida, H.: 1970, Prediction and counter measure against the liquefaction in sand deposits. Abstract of the seminar in the Port and Harbor Research Institute, 3.13.33 .

Toki, S., Tatsuoka, F., Miura, S., Yoshimi, Y., Yasuda, S. and Makihara, Y.: 1986, Cyclic undrained triaxial strength of sand by a cooperative test program. Soils Found., 26, 3, 117-128. DOI: $10.3208 /$ sandf1972.26.3 117

Townsend, F.C.: 1977, Review of factors affecting cyclic triaxial tests. Proc. Symp. Dynamic Geotech. Testing; ASTM 356 - 383.

Vucetic, M. and Dobry, R.: 1988, Cyclic triaxial straincontrolled testing of liquefiable sands. In: Advanced Triaxial Testing of Soil and Rock, Donaghe, R., Chaney, R. and Silver, M., eds., 475-485. DOI: $10.1520 / \mathrm{STP} 29093 \mathrm{~S}$

Xenaki, V.C. and Athanasopoulos, G.A.: 2003, Liquefaction resistance of sand-silt mixture: an experimental investigation of the effect of fines. Soil Dyn. Earthq. Eng., 23, 183-94. DOI: $10.1016 / \mathrm{S} 0267-7261(02) 00210-5$

Yunoki, Y., Ishihara, K., Seki, M. and Yoneda, Y.:1982, The effect of the initial effective confining pressure on cyclic triaxial shear behavior of dense sand. Proc. $17^{\text {th }}$ Japanese National Soil Mechanics Research Meeting, JSSMFE, 1649-1652. 